WISSENSCHAFTSZENTRUM BERLIN FÜR SOZIALFORSCHUNG

SOCIAL SCIENCE RESEARCH CENTER BERLIN

Thomas R. Cusack

Pablo Beramendi

\title{
Taxing Work: Some Political and Economic Aspects of Labor Income Taxation
}

SP || $2003-17$

October 2003

ISSN Nr. $0722-6748$

Research Area

Markets and Political Economy

Research Unit

Competitiveness and Industrial Change
Forschungsschwerpunkt

Markt und politische Ökonomie

Abteilung

Wettbewerbsfähigkeit und industrieller Wandel 
Zitierweise/Citation:

Thomas R. Cusack and Pablo Beramendi, Taxing Work:

Some Political and Economic Aspects of Labor Income Taxation, Discussion Paper SP II $2003-17$,

Wissenschaftszentrum Berlin, 2003.

Wissenschaftszentrum Berlin für Sozialforschung gGmbH,

Reichpietschufer 50, 10785 Berlin, Germany, Tel. (030) 25491 - 0

Internet: www.wz-berlin.de 


\section{ABSTRACT \\ Taxing Work: Some Political and Economic Aspects of Labor Income Taxation*}

by Thomas R. Cusack and Pablo Beramendi

This paper examines the development of tax regimes across the OECD countries in the latter part of the 20th century. It pays particular attention to taxes on labor income. A number of results emerge from this examination. First, not only do taxes on labor income represent a major drain on private households; they have become the mainstay of many of these countries' public sector finances. Second, taxes on labor income, and not taxes on capital, appear to be the preferred instrument of finance for those economic and political interests that advocate and support a strong (and thereby expensive) welfare state. There is little "free lunch" to be had in these welfare states; if anything, "socialism in one class" seems to be the rule. Third, while the effort at financing the welfare state this way comes at cost in terms of loss in employment, the magnitude of such loss is inversely related to the degree of wage coordination in the labor market.

Keywords: Taxation, Partisan Politics, Institutions, Varieties of Capitalism

JEL Classification: H24, J32, J50, J64

This paper was presented at the Annual Meeting of the American Political Science Association in Philadelphia and the European Consortium of Political Research Open Conference in Marburg. We gratefully acknowledge the helpful comments and suggestions of Chris Anderson, William Clark, Rob Franzese, Steffen Ganghof, Bob Hancké, and Michael Wallerstein. 
Besteuerung von Arbeit: Einige politische und ökonomische Aspekte von Steuern auf Arbeitseinkommen

In diesem Beitrag wird die Entwicklung der Steuersysteme in OECD-Ländern über die letzten Jahrzehnte des 20. Jahrhunderts unter besonderer Berücksichtigung der Steuern auf Arbeitseinkommen untersucht. Folgende Resultate können festgehalten werden.

Erstens besteht nicht nur der Großteil der Abgabenbelastung für private Haushalte aus Steuern auf Arbeitseinkommen; sie sind vor allem der Grundstock der öffentlichen Finanzen in den betrachteten Ländern. Zweitens scheinen diese Steuern auf Arbeitseinkommen und nicht etwa Kapitalertragssteuern das bevorzugte Finanzierungsinstrument gerade der politischen und ökonomischen Interessenvertreter zu sein, die sich für einen starken und somit teuren Wohlfahrtsstaat aussprechen. Dabei existiert in den Wohlfahrtsstaaten kein sog. ,free lunch', vielmehr scheint der ,Sozialismus in einer Gesellschaftsklasse' an der Tagesordnung zu sein.

Drittens lässt sich feststellen, dass diese Art der Finanzierung des Wohlfahrtsstaates Kosten in Form von Arbeitslosigkeit mit sich bringt, deren Höhe sich allerdings invers zum Grad der Koordination auf dem Arbeitsmarkt verhält. 


\section{Introduction}

Throughout the last decades labor has carried an increasing burden of taxation in the post-industrial economies. For example, Canadian workers paid about one-eight of their earnings in income taxes and social charges in 1965; by 1995 the extractions the Canadian government made from workers' payroll checks had risen to a full third of their gross salaries and wages. ${ }^{1}$ In the Netherlands, growth in the direct tax burden on workers' incomes also marked the period from the mid-sixties through the mid-nineties. But in the Dutch case, as with a fair number of other countries, these tax burdens were at significantly higher levels than those found in Canada. In the Netherlands, for example, the average worker saw the level of deductions from his or her income rise from one-third in 1965 to one-half in 1995.

What has been at work behind this development and what effect has it had on the labor market? These two questions, particularly the first, are the core concerns of this paper. In addressing these questions, we proceed as follows. Initially, we briefly discuss the problem of measuring the effective tax burden on labor and others inside the economy. We then demonstrate how, in general, the tax regimes of the OECD economies have changed from the mid-60s through the mid-90s. Second, we lay out an argument showing why taxes on labor income vary across countries and over time. We then proceed to assess the empirical strength of this argument. We do this by putting forward a specification of the argument, estimating the parameters of this model, and examining the implications of these parameter estimates. Finally, our focus shifts to examine the implications of this growth in the taxation of labor income for developments in the labor market.

A number of results emerge from this preliminary effort at examining some of the political-economic aspects of labor taxation policy. First, not only do taxes on labor income represent a major drain on private households; they have become the mainstay of developed countries' public sector finances. Second, taxes on labor income, and not taxes on capital, appear to be the preferred instrument of finance for those economic and political interests that advocate and support a strong (and thereby expensive) welfare state. Third, while the effort at financing the welfare state this way comes at cost in terms of loss in employment, the magnitude of such loss is inversely related to the degree of wage coordination in the labor market.

\footnotetext{
${ }^{1}$ The tax rates used in this paragraph are based Mendoza, et als' (1994) measure of the average effective tax rate on the income of employed workers. Some details on this measure are provided in the next section.
} 


\section{Tax Structures in the OECD}

In recent times both scholars and international institutions have made efforts to quantify taxation policies. A number have done this by constructing different measures of Average Effective Tax Rates (AETRs). ${ }^{2}$ There is an advantage to these tax rates relative to more traditional indicators (e.g., revenues obtained from a particular source of income expressed as a percentage of GDP). This advantage is that they are better (but admittedly imperfect) indicators of tax policy with respect to different and specific kinds of income and other economic stocks and flows than measures that compute the ratio of a tax category to gross domestic product.

A particular controversy has arisen on the question of the relative levels of taxation on capital and labor and the consequences these have for the economy. The OECD in particular has been concerned with this issue and has been in the lead on charging that capital has been overtaxed relative to labor. In order to compute labor and capital AETRs, it is first necessary to calculate the overall average tax rate on household income. In the case of the Mendoza, et al formulation used here this variable is equal to taxes on income, profits, and capital gains of individuals expressed as a percentage of gross income. ${ }^{3}$ The latter is defined as the sum of unincorporated business net income, household income, dividends and investment receipts, and compensation of employees less employers' social security contributions and employers' contributions to private pension plans. With this rate and with a wage variable, which is equal to compensation of employees less employer contributions to public social insurance and private pension schemes, one can compute the average effective tax rate on labor.

The average effective tax rate on capital based on the Mendoza, et al version used here draws on unincorporated business net income, household income, dividends and investment receipts, corporate taxes on income, profits and capital gains of individuals, recurrent taxes on immovable property, taxes on financial and capital transactions, and the overall economy's operating surplus.

The OECD variants differ from the Mendoza, et al AETR measures on labor and capital in a number of ways. These reflect concerns such as distributing the reported unallocable social security contributions between employers and employees, imputing income shares for employees as well

\footnotetext{
${ }^{2}$ Eurostat reports an extensive set of annual statistics on AETRs for European Union member countries as well as Japan and the United States (see e.g., Eurostat, 2000 and Martinez-Mongay, 2000). The OECD has produced two reports criticizing the earlier work of Mendoza et al (1994). The first major OECD study was by Carey and Tchilinguirian (2000) that challenged the work by Mendoza, et al (1994) and produced new AETR's that reflected the OECD position that Mendoza, et al's measures understated the tax burden borne by capital and correspondingly overstated the burden borne by labor. The second major OECD study, that by Volkerink and deHaan, criticized both the Mendoza et al measures and those put forward in the Carey and Tchilinguirian report.

${ }^{3}$ The definitions for all the AETR variables used in this paper can be found in Volkerink and deHaan (2001).
} 
as self-employed and non-employed, etc. ${ }^{4}$ The results obtained from these calculations have the potential to vary considerably.

Figure 1 displays three different versions of the AETR on labor, namely the Mendoza, et al version and the two OECD variants. However, at the level of aggregation used in the figure, i.e., OECD wide-averages, there turns out to be only one detectable difference among the three versions and this is simply the level of the AETRs and not their time trajectories. The Mendoza, et al measure is larger than the OECD variants. All of the measures rose almost unabatedly through the threedecade period under observation. The cross-country average using the Mendoza et al measure grew from 24.1 percent in 1965 to 39.5 percent in 1995. For the two OECD labor income AETRs, the corresponding figures are 22.1 percent in 1965 to 36.1 percent in 1995 and 21.5 percent in 1965 to 35.6 percent in 1995.

Along with the upward trajectory of the labor income AETRs, a common tendency during this three-decade period was for the alternative labor tax bases to increase initially and then to fall back to levels near where they started. Figure 2 below displays the evolution of the three tax bases as a share of GDP between 1965 and the late 1990s. As mentioned above, the compositions of the different tax bases used in calculating these AETRs vary. These variations are reflected in the tax revenues measured as shares of GDP. On average, Mendoza, et al's measure uses the smallest base. Again, the three series have followed similar time trajectories. All expanded in relative terms through to the late 1970 s and then reversed direction generally returning to levels close to those that prevailed in the mid-60s.

These two developments, the relentless growth in the average effective tax rate and the growth and then decline in the base against which these tax rates are applied have helped create the situation where labor income has come to provide a much larger share of the total resources the public sector extracts from the economy. For example, using the Mendoza et al measure, whereas in 196511.5 percent of GDP was taken in form of taxation on labor income by the state, that level had risen to nearly 20 percent in 1995. Even higher levels are to been seen in the two OECD series on labor AETRs. In one, the share of GDP going to the state in the form of taxation on labor income rose from about 12 to approximately 21 percent in the period from 1965 to 1995 . Using the other OECD measure, this share grew from about 15 percent to nearly 24 percent of GDP.

\footnotetext{
${ }^{4}$ The formulae used for calculating the OECD AETRs can be found in the Carey and Tchilinguirian (2000) paper or in Volkerink and deHaan (2001).
} 
Figure 1

Average Effective Tax Rates on Labor Income: Cross-Country Averages, 1965-95

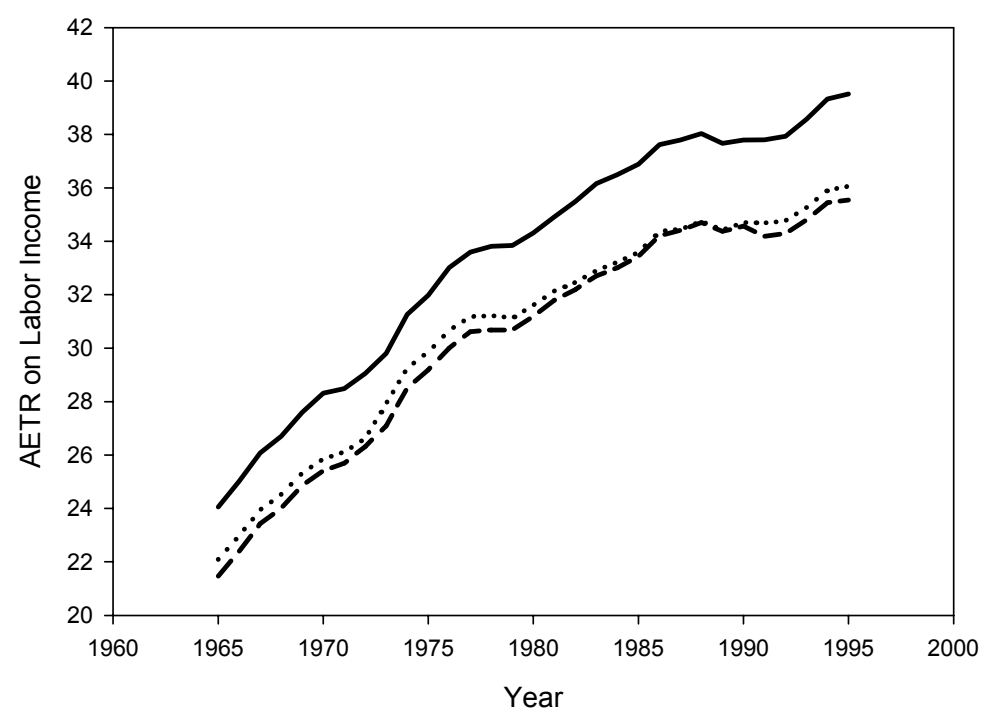

- Mendoza, et al ........ OECD vers. 1

- - OECD vers. 2

\section{Figure 2}

Relative Sizes of Labor Income Tax Bases:

Cross-Country Averages, 1965-95

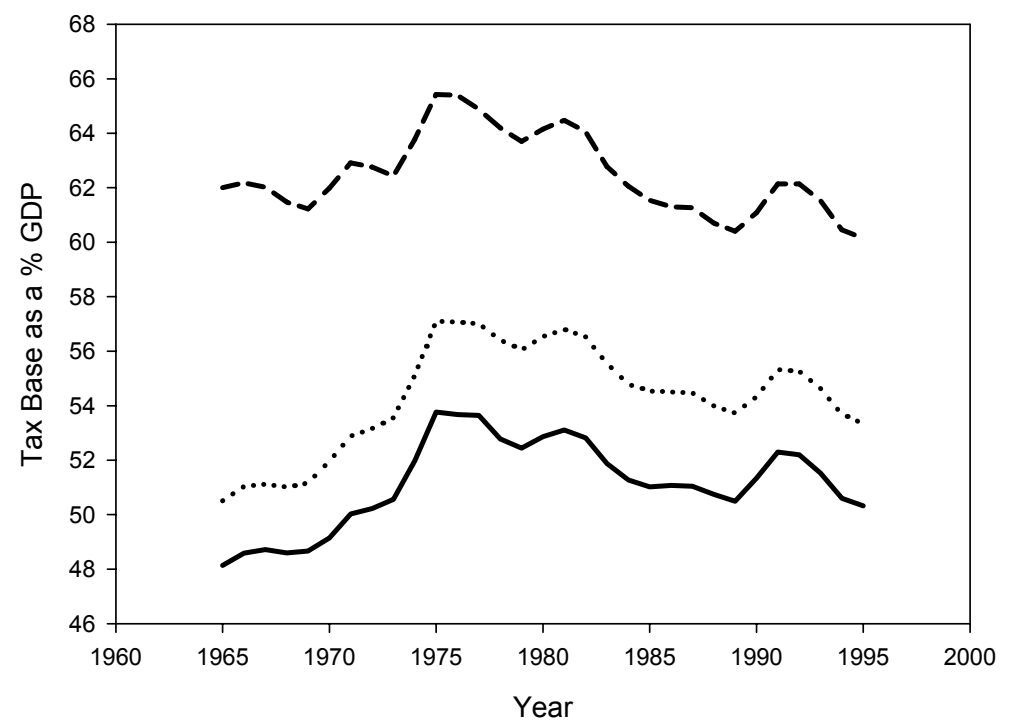

Mendoza, et al ........ OECD vers. 1 - - OECD vers. 2 
Figure 3

Tax on Labor Income as a Percent of Total Tax Revenues Cross-Country Annual Averages

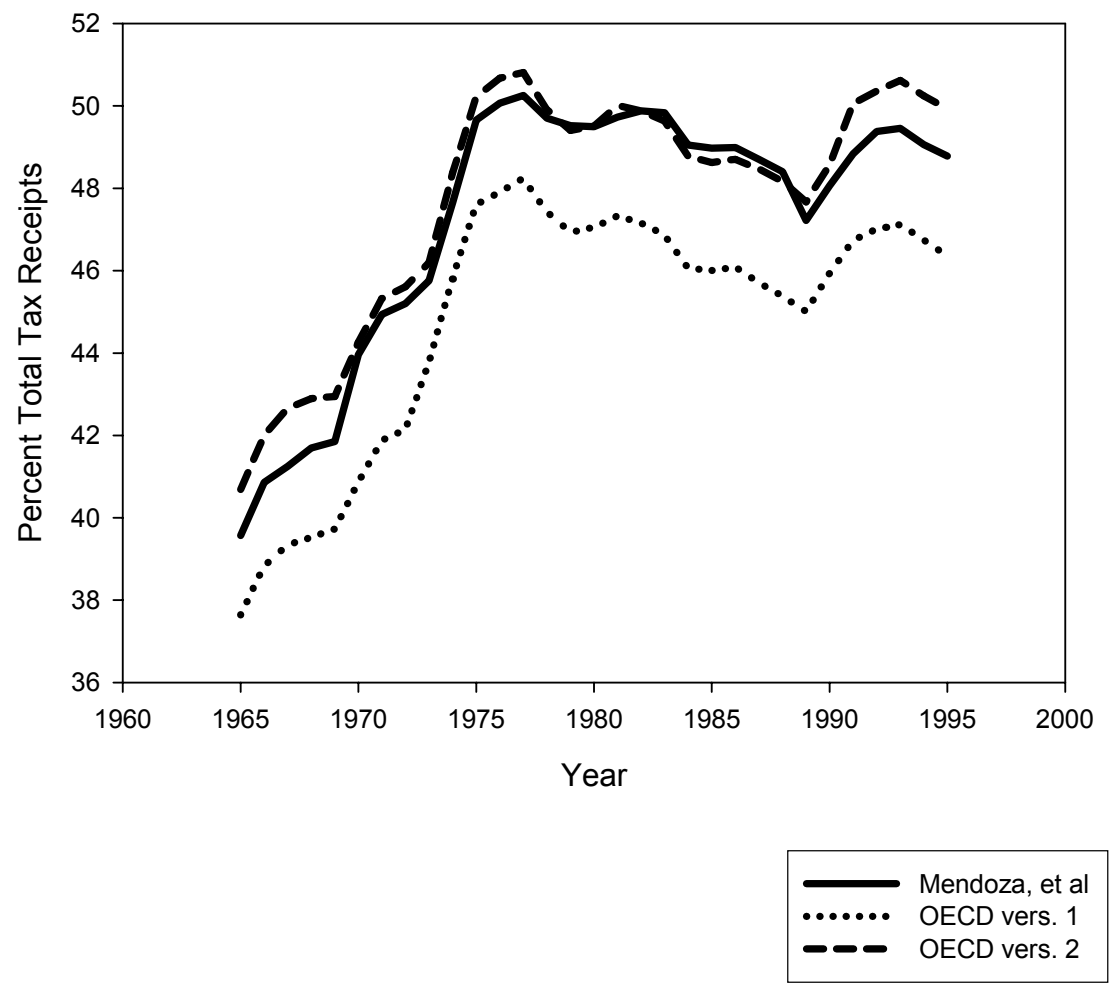




\section{Table 1}

National Tax Regimes in Liberal and Coordinated

Market Economies, 1965 and 1995

Average Effective Tax Rates on Consumption, Labor Income, Capital Income and Corporate Profits: Mendoza, et al and OECD (version 2)

\begin{tabular}{|c|c|c|c|c|c|c|c|c|c|}
\hline & \multicolumn{3}{|c|}{ Mend. } & \multicolumn{6}{|c|}{ OECD } \\
\hline & YEAR & Cons. & Lab. & Cap. & Corp. & Cons. & Lab. & Cap. & Corp. \\
\hline \multirow[t]{2}{*}{ LME Average } & 1965 & 10.4 & 15.4 & 35.3 & 27.4 & 10.9 & 14.4 & 45.8 & 36.5 \\
\hline & 1995 & 10.9 & 26.5 & 44.8 & 31.7 & 10.5 & 23.9 & 56.6 & 49.0 \\
\hline \multirow[t]{2}{*}{ CME Average } & 1965 & 14.6 & 27.5 & 19.1 & 24.0 & 13.2 & 24.6 & 28.8 & 29.6 \\
\hline & 1995 & 17.9 & 44.7 & 32.2 & 26.1 & 13.5 & 40.2 & 42.9 & 30.4 \\
\hline \multicolumn{10}{|l|}{ Indiv. LMEs } \\
\hline \multirow[t]{2}{*}{ United States } & 1965 & 6.4 & 15.4 & 36.8 & 30.4 & 6.5 & 14.0 & 47.1 & 46.3 \\
\hline & 1995 & 5.6 & 26.6 & 41.1 & 24.2 & 5.7 & 22.5 & 49.0 & 39.3 \\
\hline \multirow[t]{2}{*}{ Canada } & 1965 & 13.0 & 12.2 & 36.0 & 28.7 & 14.3 & 11.5 & 50.1 & 29.0 \\
\hline & 1995 & 12.2 & 32.8 & 47.2 & 20.1 & 11.5 & 29.8 & 56.3 & 24.0 \\
\hline \multirow[t]{2}{*}{ UK } & 1965 & 13.3 & 21.5 & 36.9 & 12.2 & 12.5 & 20.1 & 43.1 & 29.5 \\
\hline & 1995 & 16.9 & 24.8 & 46.8 & 41.2 & 15.0 & 22.0 & 63.3 & 65.4 \\
\hline \multirow[t]{2}{*}{ Australia } & 1965 & 8.7 & 12.4 & 31.3 & 38.2 & 10.3 & 12.2 & 43.0 & 41.2 \\
\hline & 1995 & 8.8 & 21.7 & 44.2 & 41.3 & 10.0 & 21.1 & 58.0 & 67.3 \\
\hline \multicolumn{10}{|l|}{ Indiv. CMEs } \\
\hline \multirow[t]{2}{*}{ Netherlands } & 1965 & --- & 33.7 & 22.2 & 18.6 & 12.7 & 28.5 & 27.1 & 18.6 \\
\hline & 1995 & 18.2 & 50.6 & 28.1 & 21.8 & 16.0 & 40.8 & 37.8 & 21.8 \\
\hline \multirow[t]{2}{*}{ Belgium } & 1965 & -- & 28.7 & 17.5 & 17.0 & 15.0 & 24.4 & 21.3 & 17.0 \\
\hline & 1995 & 16.6 & 47.1 & 36.2 & 29.4 & 15.0 & 39.3 & 44.6 & 29.5 \\
\hline \multirow[t]{2}{*}{ France } & 1965 & 22.4 & 34.4 & 15.9 & 38.9 & 18.1 & 26.8 & 23.7 & 72.3 \\
\hline & 1995 & 19.9 & 47.2 & 27.9 & 27.7 & 15.5 & 40.8 & 35.4 & 44.5 \\
\hline \multirow[t]{2}{*}{ Switzerland } & 1965 & 5.7 & 19.3 & 14.4 & 12.0 & 5.9 & --- & --- & 15.6 \\
\hline & 1995 & --- & 34.5 & 31.8 & 23.7 & 7.8 & 31.1 & 49.5 & 29.4 \\
\hline \multirow[t]{2}{*}{ Germany } & 1965 & 15.9 & 29.3 & 20.7 & 9.0 & 14.6 & 26.4 & 23.3 & 12.1 \\
\hline & 1995 & 16.7 & 42.7 & 25.0 & 5.1 & 14.1 & 38.1 & 30.1 & 7.6 \\
\hline \multirow[t]{2}{*}{ Austria } & 1965 & 17.9 & 35.3 & 14.8 & 5.6 & 13.9 & 38.5 & 22.0 & 8.2 \\
\hline & 1995 & 19.0 & 48.0 & 22.4 & 7.4 & 14.2 & 57.0 & 45.6 & 9.8 \\
\hline \multirow[t]{2}{*}{ Italy } & 1965 & 12.4 & 24.3 & 12.8 & 48.2 & 13.7 & 14.9 & 42.6 & 48.2 \\
\hline & 1995 & 15.7 & 47.1 & 32.6 & 51.4 & 14.1 & 36.5 & 41.1 & 58.2 \\
\hline \multirow[t]{2}{*}{ Finland } & 1965 & 17.1 & 22.3 & 22.5 & 31.8 & 16.8 & 19.0 & 37.1 & 44.8 \\
\hline & 1995 & 26.1 & 49.8 & 32.1 & 15.3 & 17.3 & 46.5 & 33.5 & 18.0 \\
\hline \multirow[t]{2}{*}{ Sweden } & 1965 & 16.4 & 32.7 & 30.0 & 24.7 & 14.5 & 30.6 & 32.3 & 24.8 \\
\hline & 1995 & 22.5 & 52.5 & 41.4 & 27.7 & 15.0 & 47.9 & 45.5 & 33.6 \\
\hline \multirow[t]{2}{*}{ Japan } & 1965 & 5.7 & 15.1 & 20.4 & 33.9 & 7.0 & 12.3 & 30.0 & 33.9 \\
\hline & 1995 & 6.0 & 27.7 & 44.3 & 51.3 & 6.2 & 24.1 & 66.6 & 51.3 \\
\hline
\end{tabular}

--- Data not available.

-- Corporate income AETR in right-hand panel based on Volkerink and deHaan's definition. All other OECD AETR's are based on Carey and Tchilinguirian's formulations. 
As a consequence of these developments, the tax regimes of the OECD countries have come to rely extensively on labor income. By the end of the 1970s taxes on such income amounted to approximately 50 percent of all tax revenue garnered by the public sector (see Figure 3). Note, however, that there are important differences across these countries in terms of the structures of their tax regimes (see Table 1). For example, among the group of nations considered to have Liberal Market Economies (LMEs), there is a clear tendency to avoid heavy taxation on consumption and labor and to rely to greater extent on capital for tax receipts. ${ }^{5}$ And while labor income has come increasingly under taxation within this group of countries, the rates are nowhere near as high as those found within Coordinated Market Economies (CMES). These latter countries are also particularly heavy-handed in terms of their extractions on consumption outlays while being much lighter of touch than Liberal Market Economies in the taxes they extract from capital.

This tendency for Coordinated Market Economies to tax labor more heavily than capital appears to be a fairly consistent pattern across the tax regimes of the OECD countries. Rather clear evidence on this is given in Figure 4 and Table 2 where we report the results from a series of crosssectional analyses showing the relationship between the level of coordination within an economy and the ratio of the average effective tax rates on labor and capital. ${ }^{6}$ These results bring out the point clearly that CMEs have tax regimes that place higher average effective tax rates on labor than on capital, while LMEs do the opposite. ${ }^{7}$

We know that CMEs also tend to have larger and more generous welfare states than Liberal Market Economies (Estevez-Abe, et al. 2001). In turn, then, it would appear to be the case that CMEs are financing their generous redistributive programs mainly by taxing the recipients of those programs rather than taxing recipients of other income sources. This point is clearly conveyed by Figure 5 , where the relation between labor taxation (Mendoza) as a percentage of GDP and the share of GDP that governments transfer to households is displayed.

\footnotetext{
${ }^{5}$ Liberal Market Economies and Coordinated Market Economies are terms used in the

Varieties of Capitalism Approach developed by Hall and Soskice (2001).

${ }^{6}$ The coordination measure is based on Hall and Gingerich's (2001) index.

${ }^{7}$ Similar results have been found using the two alternative OECDs sets of labor and capital AETRs.
} 
Figure 4

Coordinated Market Economies and the

Propensity to Tax Labor Income

(Mendoza vers.) Average 1965-69

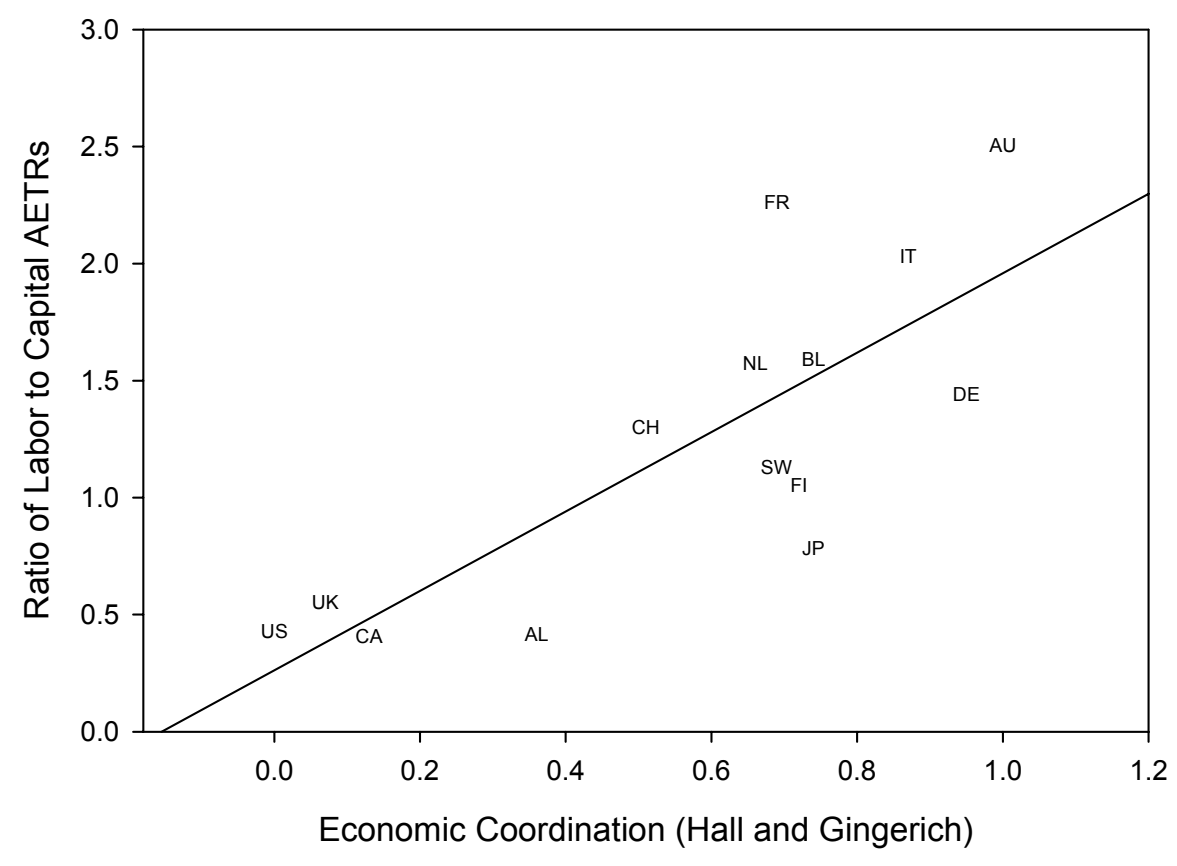

Table 2

Ratios of Labor to Capital AETRs as a Function of the Degree of Economic Coordination OLS Estimates of Five-Year Averages

\begin{tabular}{|l|c|c|c|}
\hline & Constant & Coordination & $R^{2}$ \\
\hline Mendoza et al & & & .62 \\
\hline $1965-69$ & .26 & 1.70 & $(.39)$ \\
& $(.25)$ & 1.72 & .63 \\
\hline $1970-74$ & .23 & $(.38)$ & \\
& $(.25)$ & 1.31 & .61 \\
\hline $1975-79$ & .34 & $(.29)$ & .52 \\
& $(.20)$ & 1.08 & $(.28)$ \\
\hline $1980-84$ & .40 & 1.11 & .49 \\
& $(.29)$ & $(.30)$ & \\
\hline $1985-89$ & .41 & 1.18 & .57 \\
& $(.20)$ & $(.27)$ & \\
\hline $1990-94$ & .40 & $(.18)$ & \\
\end{tabular}


This relationship between taxes on labor and transfers to households is puzzling. In general, the presence of social-democratic parties in power is more likely in a CME than it is in an LME. In this context, one would think that redistribution involves not only a progressive income tax, but also, particularly from a social-democratic perspective, an effort to make transfers between income classes (labor and capital). And yet CMEs consistently finance their social protection systems by taxing mainly labor. This puzzling situation prompts the following question: why is it that CMEs are far ahead of LMEs in taxing labor income as opposed to other sources of revenues?

\section{Figure 5}

Government Transfers and Labor Tax Receipts (Mendoza)

(14 countries, 6 five year averages)

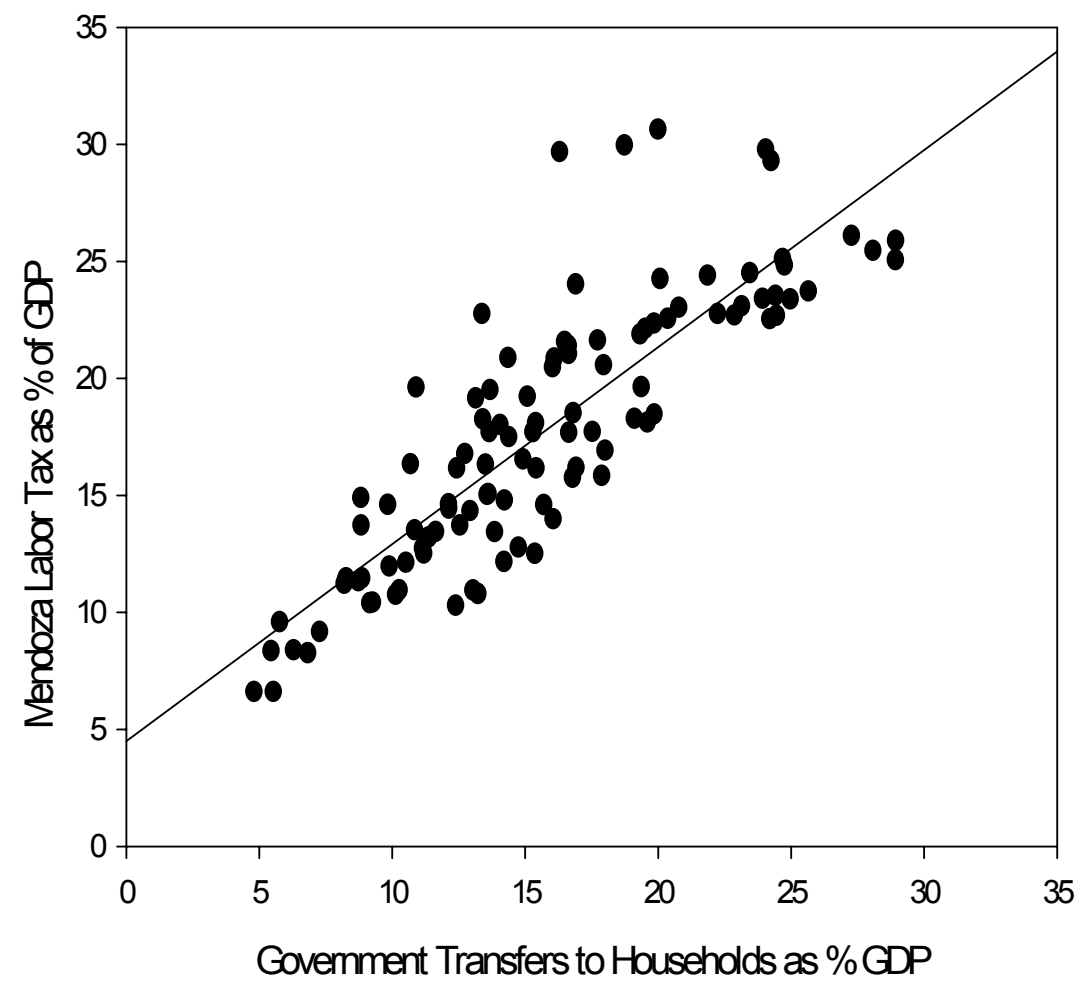

\section{Setting Tax Policy}

Our answer to this question is that welfare policy within the OECD countries is principally a matter of redistribution within one class. One of the main policy instruments used to achieve this is taxation on labor income. In this section we outline the forces at work in shaping this policy and pay particular attention to specific institutional features of the economic and political systems and how they contribute to the creation and maintenance of this policy.

A central feature of the organization of the economy is the degree of wage coordination between capital and labor. Indeed, this is 
conventionally regarded as a crucial aspect of the difference between Liberal and Coordinated Market Economies (Hall and Soskice 2001). Let us consider briefly the nature of such differences and their implications for labor income tax policies.

LMEs rely heavily on markets as the main mechanism to allocate resources. In LMEs firms coordinate their activities via competitive market arrangements. Relations between capital and labor are organized by individuals and not by associations. Capitalists value their capacity to adjust to market fluctuations; and so too does labor by investing in portable, general skills. Neither has an incentive to coordinate outside the market.

Alternatively, markets are organized very differently in CMEs. Firms find incentives to coordinate with unions and the government around a fundamental "non-market based" equilibrium between capital and labor. An equilibrium such as this becomes politically effective via the wage coordination compromise between capital, labor and the government.

By virtue of this compromise labor agrees to restrain wage demands, thereby contributing to lower inflation and better economic conditions, but most importantly for itself, gains a degree of income insurance for workers. ${ }^{8}$ Government uses fiscal policy to compensate labor for its sacrifice and thereby reduces the costs of the compromise. It does this through a large welfare state that provides labor with an insurance system that guarantees both a good income level in periods of economic downturns and longer-term earnings (pensions). In addition, labor unions obtain the capacity to ensure an egalitarian wage distribution and the political control over the implementation of a large number of public policies (Coe and Snower 1997; Swenson and Pontusson 2000).

Coordination is beneficial for employers because it avoids the disruption in production associated with industrial disputes. In addition, the welfare state is also functional from the perspective of capitalists in that it contributes to the maintenance of a labor force with specific skills (Iversen and Soskice 2001). Finally, the employer's share of the compromise is to accept solidaristic wage policies and a large welfare state. In short, high levels of wage coordination imply that, in exchange for the wage moderation on the part of labor, capitalists accept that the government (together with the unions) develops a large, very costly, public insurance system.

Because of the compromises involved in wage coordination, governments of CMEs, as opposed to those of LMEs, devote a larger share of their GDP to social transfers and public services (Estevez-Abe et al., 2001). As a result, governments in CMEs need to raise a larger amount of public revenues. This brings us to the relationship between the organization of economic institutions and the design of taxation structures. The question is who is going to bear the cost of the highly developed

\footnotetext{
${ }^{8}$ For a detailed characterization of the nature of this compromise see Cameron (1984),
} Regini (1984), Wallerstein, Golden and Lange (1997) and Wallerstein and Golden (2000). 
welfare states at work in CMEs. Our discussion in the previous section of the general patterns of taxation in OECD countries suggests that the answer to this question is mainly labor as opposed to capital. There are two reasons why this is the case.

First, governments tax labor more than capital because taxing the latter has become increasingly difficult over time. The exits available to capital have grown in the modern era, thereby making it ever more difficult for government to tap this source of income (Genschel 2002 and Ganghof 2003). Such has not been the case for labor. Mobility of this factor of production has been and remains quite limited.

The second reason relates to wage coordination and the differences between CMEs and LMEs. It concerns the potential impact that different tax structures could have on the incentives of capital to maintain wage coordination with labor and, ultimately, to endorse the development of the welfare state. Simply put, if a tax structure were to place the cost of the welfare state on the shoulders of capital, it would eliminate the incentives for capitalists to coordinate with labor. High taxes on capital reduce firm owners' net profits, harming investment and, in the long run, lowering economic growth. In such a case, the reduction in their net income would outweigh the benefits they obtain from coordinated wage bargaining.

These two points clarify why the cost of the welfare state must be carried principally by labor. But for labor this is a necessary evil. Getting the benefits provided by a generous welfare state only comes at the price of paying its cost. This trade-off is one of the hallmarks of a Coordinated Market Economy.

The constraints on capital income taxation and the opportunity costs they impose are also relevant to an understanding of the role of partisanship in shaping the variation in tax policies of OECD countries. Political parties at different ends of the ideological spectrum promote the interests of different groups of supporters and hold opposed views as to what the desirable level of redistribution should be.

Since the contributions of Hibbs $(1977,1987)$ and Kirschen, et al (1964), scholars endorsing the partisanship approach to public policy have argued that social democratic and other left-wing parties tend to promote the interest of labor, while conservative parties tend to promote the interests of "upscale" groups. Generally, promoting the interests of labor is understood as taxing and spending more, whereas advancing the interests of upscale groups is seen as taxing and spending less. Thus, it is reasonable to expect a good deal of the variation in public policy outcomes to be the result of the ideological profile of the parties in control of government. For example, Esping-Andersen (1985) provided a detailed analysis of how Scandinavian social democrats used the welfare state to forge stable electoral coalitions leading them to, and keeping them, in power. In addition, many other students of comparative political economy have produced a great deal of evidence supporting the claim that left- 
(right-) wing parties provide higher (lower) levels of redistribution. (Hibbs 1992, Franzese 2002, and Bartels, 2003).

The general evidence on the effects of partisanship is difficult to dispute. $^{9}$ Nevertheless, the existence of the above-mentioned trade-off between redistribution within labor and redistribution between income classes qualifies our understanding of the relationship between partisanship and redistribution in the following sense. A large welfare state is only viable under the condition that capital not be taxed too heavily. Thus, greater redistribution by left-wing governments should lead to higher levels of taxation on labor.

Simply put, left-wing governments cannot promote the interests of labor by financing generous transfers with taxes on capital income. Rather, the policy choice is about the promotion of the interests of different types of workers. By choosing to combine very generous transfer policies with high levels of labor income taxation, left-wing governments stand for the interests of the lower part of the wage distribution. In contrast, by choosing a strategy based on reduced levels of generosity and lower tax rates on labor, right wing governments promote the interests of high wage and salary earners, those who would bear the greatest costs under progressive income tax schemes. Provided one or another party is in office for a sufficiently long period, these two different strategies should become sharply reflected in the taxation policies of OECD governments. ${ }^{10}$

Nonetheless, the clarity of the reflection is contingent upon specific aspects of the design of political institutions. ${ }^{11}$ Some of these institutions facilitate the unencumbered translation of ideological preferences into policy outcomes. Other institutional settings have both incentives and constraints that moderate or mute this translation. The rich literature on veto players and veto points is an illustration of this general proposition. For example, Tsebelis' (1995) theory of veto players points out how the presence of such actors militates against significant policy change. Huber, Ragin and Stephens (1993) and Huber and Stephens (2001) produce evidence that the number of institutional veto points ${ }^{12}$ existing in a country has a constraining effect on the levels of welfare effort. More qualitatively, Immergut (1992) shows how health policy outcomes in France, Switzerland and Sweden were affected by the structure of legislative veto points existing in these countries.

All these contributions suggest that the translation of party platforms into public policies is far from automatic. While partisan

\footnotetext{
${ }^{9}$ For a dissenting and critical view, see Blais, et al, 1993 and Imbeau, et al, 2001.

${ }^{10}$ For an insightful analysis of how political instititutions influence the shape of taxation systems, see Steinmo (1993). It should be pointed out that the results reported in Boix (1999), Swank and Steinmo (2002) and Bretscher and Hettich (2002) are not fully consistent in showing how partisanship influences tax policy.

${ }^{11}$ See Schmidt 1996, 2002.

12 These include federalism, parliamentary/presidential government, proportional representation/single member districts, bicameralism, and the possibility to call referenda (Huber, Ragin and Stephens (1993: 728). In addition, see Schmidt (2000, 2002), Obinger and Kittel (2003), and Cusack and Fuchs (2003).
} 
differences exist, the size of these differences in terms of public policy is likely to depend on the pattern of executive-legislature relations and in particular, the relative power of these two institutions in the setting of public policy.

Ultimately, the relative power depends upon the electoral system in use. For a variety of reasons (Lijphart 1999), strong executives seem to emerge in those political systems that use majoritarian voting rules. Likewise, weak executives (and, correspondingly, strong legislatures) have emerged in political systems that rely on proportional representation. How does this difference shape partisan effects on tax policy?

Assuming that majoritarian electoral systems simplify elections to a competition between two major alternatives (Duverger 1954; Cox 1997) and that preferences about taxation can be subsumed in a single dimension, then the median voter theorem applies. In order to win the election, parties on both sides of the ideological spectrum must articulate their platforms and policies ${ }^{13}$ around the position of the median voter. As a result the scope for partisan differences in majoritarian electoral systems is constrained by the nature of political competition. Therefore, one would see modest differences between left and right policies.

Electoral systems based on proportional representation (PR) shape political competition in exactly the opposite direction. In contrast to majoritarian systems, policy outcomes are expected to reflect positions further away from the median voter on either side of the ideological spectrum. As a result, the partisan effects on policy outcomes will be sharper.

In order to lend some substance to this claim we make use of a simplified version of the model developed by Austen-Smith and Banks (1988). Consider a legislature with three parties $\left(P_{K}\right)$. Subscript $K$ defines the ideological position of the parties $(K=\{L, C, R\})$, where subscripts $L, C$ and $\mathrm{R}$ stand, respectively, for left, center and right. Each party has a weight $\left(\mathrm{W}_{\mathrm{K}}\right)$ that represents the share of seats in the legislature. Thus the weighted ideological profile of the legislature is given by $\sum P_{K} * W_{K} \cdot{ }^{14}$

The process of government formation is driven by parties' positions on a single dimension, namely taxation policy. How do they bargain and what is the likely policy outcome? To answer this question it is necessary to introduce a number of additional assumptions. First, parties have perfect information. Second, the sequence of the game between the parties in the legislature is as follows. In the first stage of the game, $t=1$, the party with the largest number of seats proposes a coalition to another party. The proposal may be accepted or rejected. If the proposal is rejected, then, at

\footnotetext{
${ }^{13}$ The claim that policies reflect platforms is based on the assumption of retrospective voting.

${ }^{14}$ Note that the measure of ideological center of gravity used in the empirical analysis below is formulated in the same way.
} 
$t=2$, the party with the second highest number of seats has the initiative. It proposes a different coalition. If this proposal is rejected by its recipient, the party with the lowest weight gets to propose at $t=3$. At this stage if the parties cannot reach an agreement, a "special" government is formed such that the payoff for the three parties is 0 . Figure 6 provides a graphic representation of the bargaining process. In addtion, we take as given the result proved by Austen-Smith and Banks (1988: 416-417) that in PR systems the party adopting the position of the median voter $\left(P_{c}\right)$ is the one that receives the lowest number of votes.

Each party's strategy consists of two elements: a proposal and a response to others proposals. The proposal $\left(\phi_{\mathrm{K}}\right)$ contains three elements, namely, a proposed set of coalition parties $(C)$, a policy position $\left(p_{K}\right)$ and a (proposed) distribution of portfolios $\left(g_{K}\right)$ within the coalition. The second element of the strategy is set of responses to others' proposals $\left(r_{K} \rightarrow\{0,1\}\right.$, where 0 means rejection and 1 acceptance).

The selection of a particular strategy is driven by two considerations, the utility and the opportunity costs attached to proposals and responses. The utility of any given proposal is a function of its policy position $\left(p_{K}\right)$ and its distribution of portfolios $\left(g_{K}\right)$. The opportunity costs are defined as the payoffs that would have been obtained had the party chosen differently. For instance, the opportunity cost of a party accepting a proposal at $t=2$ is the payoff that this party would have obtained from the outcome implemented at $t=3$. In sum, the opportunity costs depend on the responses of parties to the proposals made at each stage. Let $\alpha(\phi) \rightarrow\{0,1\}$ represent the product of party responses to any given proposal $\phi$ at stages $1-3$ in the model.

More formally, the utility function of any given party $P_{K}$ is defined as:

$U_{K}\left(\phi_{K}\right)=U_{K}\left(p_{K}, g_{K}\right)^{*} \alpha\left(\phi_{K}\right)$

where the functional form of $U_{K}$ is set by Austen-Smith and Banks (1988) to be quasi-linear on $\mathrm{g}$ and quadratic on the differences between the expected policy outcome $(y)$ and the preferred policy position of each party:

$U_{K}\left(p_{K}, g_{K}\right)=g_{K}-\left(y-p_{K}\right)^{2}$ 
Figure 6

The Sequence of the Bargaining Process $\left(W_{1}>W_{2}>W_{3}\right)$

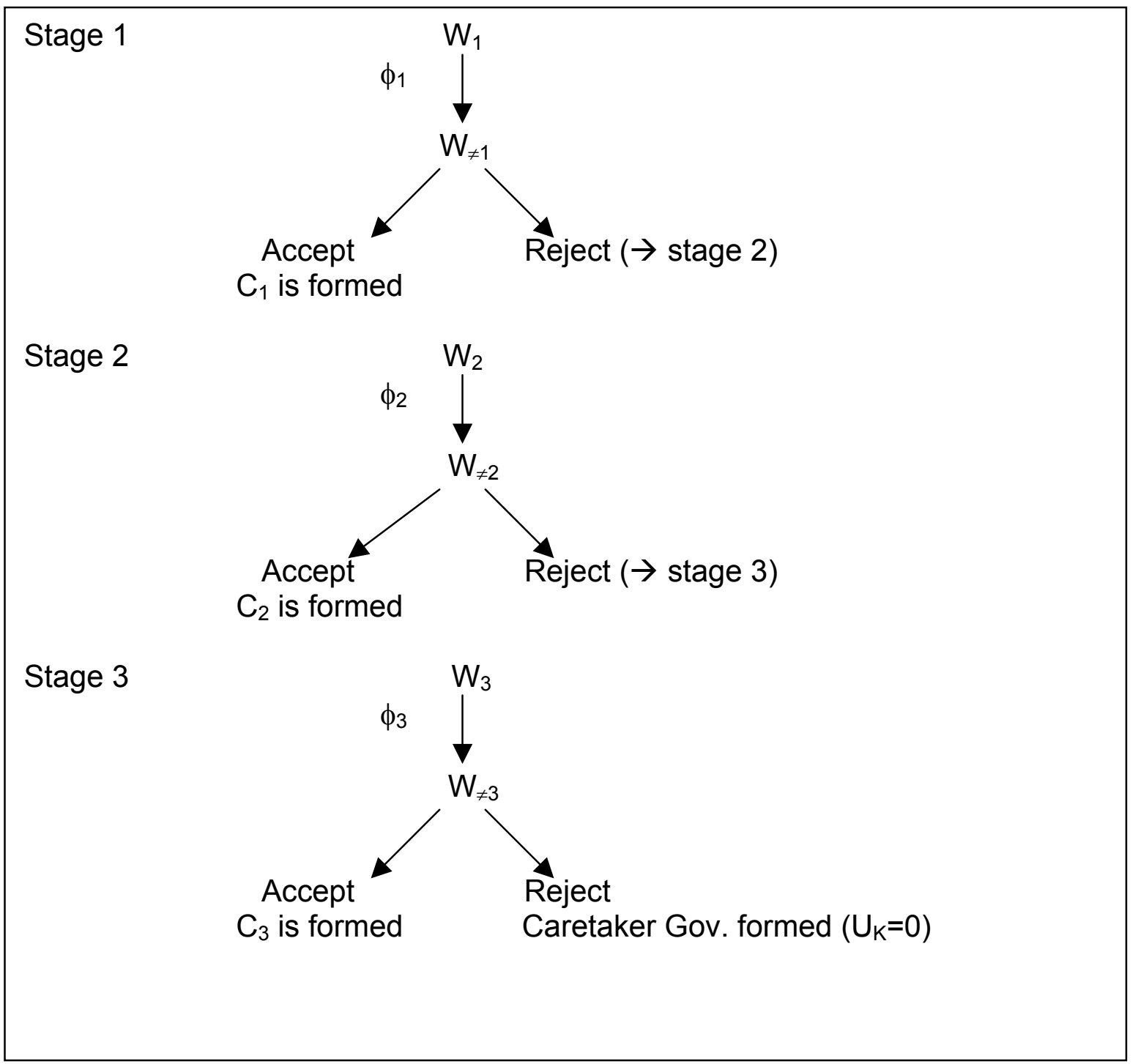

Subsequently, the opportunity costs at the different stages $(\mathrm{OC}(\mathrm{s}))$ of the game are defined as:

$\left.\begin{array}{l}\mathrm{OC}(3)_{\mathrm{K}}\left(\phi_{\mathrm{K}}, \mathrm{r}\right)=0 \text { (by assumption) } \\ \mathrm{OC}(2)_{\mathrm{K}}\left(\phi_{\mathrm{K}}, r\right)=\alpha_{3}\left(\phi_{\mathrm{K}}\right)^{*} U_{\mathrm{K}}\left(p_{3}, g_{3}\right) \\ \mathrm{OC}(1)_{\mathrm{K}}\left(\phi_{\mathrm{K}}, r\right)=\alpha_{2}\left(\phi_{\mathrm{K}}\right)^{*} U_{\mathrm{K}}\left(p_{2}, g_{2}\right)+\left(1-\alpha_{2}\left(\phi_{\mathrm{K}}\right)\right)^{*} \mathrm{OC}(2)_{\mathrm{K}}\end{array}\right\}$

The interaction between the parties is modeled as a legislative bargaining game with perfect information. In this context, a coalition will be in equilibrium if there is a proposal $\left(\phi^{*}\right)$ that maximizes the utility of the proponent party and a response by the joining party $\left(\alpha^{*}=1\right)$ that maximizes 
the latter's utility. ${ }^{15}$ For the purposes of our argument, the key aspect of this model is the nature of the policy outcome of the bargaining solution. By establishing the characteristics of the policy that satisfies the equilibrium condition, the model highlights how political competition in PR systems reinforces partisan effects while dampening those effects in majoritarian systems.

Let us illustrate the nature of policy outcomes with two examples. First, consider the case in which no party holds the majority $\left(W_{L}, W_{C}, W_{R}<\right.$ $1 / 2$ ) and the ranking of voting shares is $W_{L}>W_{R}>W_{C}$ (recall that, by assumption, the ranking of seats shares would be either $W_{R}>W_{L}>W_{C}$ or $W_{L}>W_{R}>W_{C}$ ). At time $t=1 P_{L}$ offers a coalition proposal to $P_{C}$. He does not offer it to $P_{R}$ because it anticipates its negative response. Given that at time $=2$ it is $P_{R}$ who gets to propose, the opportunity cost of accepting a proposal at time $=1$ is very high (see expression $3-\mathrm{OC}(1)$ above), which in turns implies that, in order to gain $P_{R}$ 's acceptance, $P_{L}$ would have to make such concessions that the coalition outcomes would no longer be optimal. Thus $P_{L}$ chooses $y$ and $g_{\llcorner}$to maximize its own utility and the chances of getting a positive response from $P_{C}$. More formally, making use of xpression (2) above, $P_{L}$ ' $s$ chooses $y$ and $g_{L}$ to maximize the joint utility of the proposed coalition partners:

$$
\operatorname{Max} g_{L}-\left(y-p_{L}\right)^{2}+\left(G-g_{L}-\left(y-p_{C}\right)^{2}\right)
$$

where $G$ stands for the total number of portfolios in the coalition. Solving this problem, the coalition policy outcome required to obtain an equilibrium is such that

$\mathrm{y}^{*}=\left(\mathrm{p}_{\mathrm{L}}+\mathrm{p}_{\mathrm{C}}\right) / 2$

which implies that the taxation policy implemented by this coalition government would be in between the preferred policy positions of the leftwing party and the party representing the position of the median voter. ${ }^{16}$

A second example can be seen in the situation where one party holds the majority in the legislature $\left(W_{k}>1 / 2\right)$, no bargaining between parties occurs. Under such circumstances, the policy outcome will reflect the policy position that maximizes the utility of the members of the winning party $\left(\mathrm{y}^{*}=\mathrm{p}_{\mathrm{K}}{ }^{*}\right)$, which, in turn, corresponds to that of the median legislator within the winning party. Regardless of the side of the ideological spectrum being considered, this position would always be further away from the median than in majoritarian systems.

\footnotetext{
${ }^{15}$ Formally, these two conditions require that (1) $U_{K}\left(\phi^{*}{ }_{K}\right)>O C(s)_{K}\left(\phi^{*}{ }_{K}, r\right)$ and $(2) \alpha^{*}\left(C_{K}\right.$, $\left.p_{K}, g_{K}\right)=1$ if $U_{K}\left(\phi^{*}{ }_{K}\right) \geq O C(s)_{K}\left(\phi^{*}{ }_{K}, r\right)$. Condition (2) implies that the proposal made by the party must be Pareto-efficient (Austen-Smith and Banks 1988: 422).

16 A symmetrical result would be obtained if the ranking shares of parties were $W_{R}>W_{L}>W_{C}$.
} 
In conclusion, the model shows that whereas in majoritarian systems public policy will be oriented towards satisfying the median voter, in PR systems policy will appeal to the median supporter of the winning coalition, who need not be the median voter. In the latter case partisan preferences are more clearly reflected in policy outcomes. What does this imply? We should expect that where strong executives exist, the partisan effects on policy outcomes are muted. As a consequence, one would see modest differences between left and right policies. On the other hand, partisan preferences will be given fuller rein in systems where the legislature is dominant and the executive weak. Tax policy will more fully reflect the partisan preferences of the dominant parties in the legislature and not in the electorate.

To sum up, our analysis of the determinants of labor income tax policy has pointed out a fundamental trade-off: large levels of redistribution on the expenditure side need to be funded mainly by taxing labor income. By implication, those factors conventionally associated with larger levels of redistribution should be found positively associated with higher tax rates on labor. More specifically, the following testable propositions can be derived from our argument:

- A high level of wage coordination is expected to be positively and significantly associated with higher tax rates on labor.

- Left-wing governments are expected to be positively and significantly associated with higher taxes on labor. Alternatively, right-wing governments are expected to produce lower taxes on labor.

- The magnitudes of these partisan differences are expected to be larger in political institutional settings where the legislature is dominant and the executive weak.

Later in this section we provide an empirical test of these three propositions, but first allow us to specify the control variables in our analysis and say something about the data and design used here.

In addition to the variables considered in the main part of our argument, the empirical specification of the determinants of average effective tax rates include a number of controls. First, we include the level of electoral participation. We hypothesize this variable to be negatively related to the average effective tax rate on labor income. The general line of argument here is that higher levels of electoral participation bring in more voters who are averse to high tax rates on labor. This in turn signals to politicians the increased electoral unpopularity of such policy and should result in lower tax rates on labor.

The general point can be seen by considering those that normally vote and those that do not. For example, one group with high rates of electoral participation is the very rich. These people are happy to support high labor tax rates. Such are likely to lower their own tax rates. High- 
income earners also can be expected to support higher tax rates on labor since they themselves have both the resources and the incentives to legally use the complexities of the tax system to avoid being taxed. They, too, normally vote. The unemployed and retired are net recipients of transfers. It is in their interest to support high taxes on labor since this leads to higher income for them. Certainly the latter group, which is very large and is known for its widespread electoral participation, would support higher taxes on labor income source as long as the transfers they receive increase. On the other hand, medium- and low-income earners have good reason to be averse to higher labor income tax rates in that earnings from labor represent their only income source and an increase in this rate implies a greater loss. It is this group of voters who are likely to be fluctuating between participation and non-participation. Movement in the direction of the first option would increase the level of voter resistance to taxation on labor while movement in the other direction would lower that resistance.

Next we need to take into account the effects produced by the generosity of welfare programs. The budget constraint on governments implies that, other things being equal, an increase in the levels of generosity of welfare programs (be it in the form of the rate of transfers or the eligibility for recipient status) must have a positive and significant impact on the levels of revenues extracted. Since labor income has been shown to be the main source of revenues for OECD governments during the period of interest, an increase in the levels of generosity is expected to be associated with an increase in the levels of average effective tax rates on labor.

Finally, we consider variation in the size of the demographic burden. The effect on the level of the average effective tax rate on labor income of this variable is expected to be positive. The higher the share of the population dependent on the state, the greater is the need for the latter to extract revenues from the economy. As in the case of generosity, this requirement to extract further revenues is expected to lead to an increase in the average effective tax rates on labor.

In an effort to evaluate the empirical utility of these ideas, we have specified a panel regression equation and estimated that equation using data on 14 OECD countries for six five-year periods. ${ }^{17}$ The equation takes the following form:

$$
\begin{gathered}
L T R_{i t}=\alpha+\beta_{1} C C O G_{i t}+\beta_{2} L C O G_{i t}+\beta_{3} L E G_{i t}+\beta_{4} L C O G_{i t} * L E G_{i t}+\beta_{5} E P_{i t} \\
+\beta_{6} W C_{i t}+\beta_{7} D B_{i t}+\beta_{8} G E N_{i t}+\varepsilon_{i t}
\end{gathered}
$$

${ }^{17}$ The equation has been estimated three times, once using the Mendoza tax rates and then with the two variants from the OECD. Note that missing data problems for one of the OECD variants reduced the number of countries to thirteen. The fourteen countries included in the first two estimation efforts include Australia, Austria, Belgium, Canada, Finland, France, Germany, Italy, Japan, Netherlands, Sweden, Switzerland, United Kingdom, and the United States. Switzerland is the country for which it was not possible to estimate the equation for the second of the OECD variants. 
Table 3 below provides the definitions for the variables specified in the equation.

Estimation results for this equation using OLS with panel corrected standard errors (Beck and Katz, 1995, 1996) are reported in Table 4. The estimated effects are similar across the three different data series used and so we focus our attention on the results reported in the first column. In general, the fit of the equation to the data appears satisfactory in all three instances. One problem, however, shows up in the two OECD series that is not evident in the case of the Mendoza data series; namely, there is some evidence, using the Lagrange multiplier test, of autocorrelated error.

With the Mendoza data as with the OECD series we see that all of the parameters for the control variables take on the signs expected of them and are statistically significant. Thus, both the prevailing level of generosity of the welfare state, as well as the relative size of an important part of the welfare state's clientele, have the predicted positive impacts on the level of the average effective tax rate on labor income. In addition, the anticipated negative effect of widespread electoral participation is registered. The higher the level of electoral participation, the lower the rate of taxation on labor income.

The impact of wage coordination on labor tax rates is positive (and statistically significant) as predicted. Thus, industrial relations systems with structural features that allow or promote highly coordinated wage bargaining will be marked by far higher tax rates on labor income than those systems where little or no such features exist. Given the parameter estimate (in column 1), a system with centralized bargaining by peak confederations would likely have an average effective tax rate on labor income approximately eight percentage points higher than a system with fragmented wage bargaining confined to individual firms or plants, all else being equal.

Examining the estimated parameters on the individual partisan and institutional variables in the model allows one to build up a picture of the degree to which partisanship affects tax policy and how the institutional context mutes or amplifies this effect. First, let us examine the effects of partisanship. We have a partisan term describing the cabinet and one describing the legislature. The parameter on the cabinet term is positive and statistically significant. Given the measure being used for the partisan character of the cabinet, this parameter implies that leftist governments have policies that entail higher levels of average effective tax rates on labor income as predicted. On the other hand, the parameter on the partisan character of the legislature turns out to be negative, although statistically insignificant.

This seemingly contradictory indication that leftist legislatures follow policies of lower taxation on labor needs to be seen in light of the fact that the effect of the partisan character of the legislature is contingent on the relative institutional strength of the legislature. This latter impact is 
captured by the parameter on the interaction between the strength of the legislature and the partisan measure. The parameter on the constituent term, Legislative Center of Political Gravity, only has meaning in the situation where Legislative Institutional Dominance is zero (i.e., where the executive is completely dominant), and then its effects are statistically indistinguishable from zero.

The parameter for the other constituent term in the interaction, namely, the coefficient on Legislative Institutional Dominance variable, is negative and clearly statistically significant. This points to the conclusion that when the partisan orientation of the legislature is on the far right then the effect on tax policy is to sharply lower the level of the average effective tax rate on labor income by an amount that is contingent on the degree of legislative dominance.

At the same time, the parameter for the interaction between the legislative partisanship and legislative institutional term brings out the amplifying effect of a legislature that is both leftist and strong vis-à-vis the executive. This can be illustrated by drawing on a few examples of the model's predictions under a number of conditions where the cabinet and the legislature are unified or divided in terms of partisanship.

The first panel of Table 5 (panel a) provides examples where the cabinet and legislature have common ideological orientations. On the left hand side of the panel we see the effects of partisanship where the executive is weak. Here there is a gaping contrast between a unified government of the left and one of the right. In contrast to rightist governments, leftist governments follow a policy that taxes labor income heavily. On the right hand side of the panel, which illustrates the effects of partisanship where government is unified but the executive is strong, one sees that while leftist governments continue to tax labor income more heavily than rightist governments, the contrast between the left and the right is much reduced. 


\section{Table 3}

Variables in Model Predicting Average Effective Tax Rate on Labor Income

\begin{tabular}{|c|c|}
\hline Variable Label & Variable definition. \\
\hline$L T R_{i t}$ & $\begin{array}{l}\text { Average effective rate of taxation on labor income, period average. Three } \\
\text { variants from Mendoza, et al and the OECD. Data used for construction of } \\
\text { these series derive from the OECD's National Accounts of OECD Countries, } \\
\text { Detailed Tables, Volume II, various annual issues. }\end{array}$ \\
\hline$C C O G_{i t}$ & $\begin{array}{l}\text { Cabinet center of political gravity, average for period. This is a weighted } \\
\text { measure of political orientation of the governing coalition's ideology using the } \\
\text { Castle-Mair codings of parties' positions on a left-right scale. The data for this } \\
\text { and the LCOG variable are described in Cusack (1997) and available at the } \\
\text { following web site: <http://www.wz-berlin.de/mp/ism/staff/cusack_data_sets. } \\
\text { en.htm\#data> }\end{array}$ \\
\hline$L C O G_{i t}$ & $\begin{array}{l}\text { Legislative center of political gravity, average for period. Similar to the cabinet } \\
\text { measure but based on the parties within the legislature. }\end{array}$ \\
\hline$L E G_{i}$ & $\begin{array}{l}\text { The extent to which parliament dominates the executive: based on Lijphart's } \\
\text { (1999) executive-parties dimension. This (Lijphart's first dimension) } \\
\text { distinguishes political systems on the bases of the relative frequency of } \\
\text { minimal winning one party cabinets, the effective number of parliamentary } \\
\text { parties, the degree of executive dominance, the extent of electoral } \\
\text { disproportionality, and the degree of interest group pluralism. The factor score } \\
\text { has be transformed so that the value for the system with the most executive } \\
\text { strength and least legislative strength is set to zero. }\end{array}$ \\
\hline$L C O G_{i t} * L E G_{i}$ & $\begin{array}{l}\text { Interaction between legislative center of political gravity and the executive- } \\
\text { parties dimension }\end{array}$ \\
\hline$E P_{i t}$ & $\begin{array}{l}\text { Electoral participation: Average percentage of electorate participating in } \\
\text { elections during period. The data on this variable derives from the Institute for } \\
\text { Democracy and Electoral Assistance's web site <http://www.idea.int/> }\end{array}$ \\
\hline$W C_{i t}$ & $\begin{array}{l}\text { Kenworthy's wage coordination index, period average. Date set available at } \\
<\text { http://www.emory.edu/SOC/lkenworthy>. }\end{array}$ \\
\hline$D B_{i t}$ & $\begin{array}{l}\text { Demographic burden. Retired population and unemployed expressed as a } \\
\text { percentage of total population, period average. Data based on information } \\
\text { derived from various annual issues of the OECD's Labour Force Statistics. }\end{array}$ \\
\hline$G E N_{i t}$ & $\begin{array}{l}\text { Generosity of welfare system. The ratio of government transfers to } \\
\text { households as a percentage of GDP to } D B \text {, the demographic burden. Period } \\
\text { average. Data can be found at <http://www.wz-berlin.de/mp/ism/staff/cusack } \\
\text { data_sets.en.htm\#data> }\end{array}$ \\
\hline
\end{tabular}


Table 4

Panel Estimation Results for Model Predicting Average Effective Tax Rate on Labor Income (5 year averages)

\begin{tabular}{|c|c|c|c|}
\hline & $\begin{array}{c}\text { Mendoza } \\
\text { AETRs }\end{array}$ & $\begin{array}{l}\text { OECD (1) } \\
\text { AETRs }\end{array}$ & $\begin{array}{c}\text { OECD (2) } \\
\text { AETRs }\end{array}$ \\
\hline $\begin{array}{l}\text { Cabinet Center of } \\
\text { Political Gravity }\end{array}$ & $\begin{array}{l}1.50^{* *} \\
(.72)\end{array}$ & $\begin{array}{l}1.80^{*} \\
(1.11)\end{array}$ & $\begin{array}{l}1.85^{*} \\
(1.07)\end{array}$ \\
\hline $\begin{array}{l}\text { Legislative Center } \\
\text { of Political Gravity }\end{array}$ & $\begin{array}{l}-5.11 \\
(3.85)\end{array}$ & $\begin{array}{l}-1.50 \\
(3.79)\end{array}$ & $\begin{array}{l}-3.18 \\
(3.96)\end{array}$ \\
\hline $\begin{array}{l}\text { Legislative } \\
\text { Institutional } \\
\text { Dominance }\end{array}$ & $\begin{array}{l}-16.57^{* * *} \\
(3.96)\end{array}$ & $\begin{array}{c}-21.71^{* * *} \\
(4.50)\end{array}$ & $\begin{array}{c}-24.20^{* * *} \\
(5.65)\end{array}$ \\
\hline $\begin{array}{l}\text { Legislative Center } \\
\text { of Political Gravity * } \\
\text { Legislative } \\
\text { Institutional } \\
\text { Dominance }\end{array}$ & $\begin{array}{l}8.77^{* * *} \\
(1.98)\end{array}$ & $\begin{array}{c}10.24^{* * *} \\
(2.25)\end{array}$ & $\begin{array}{l}11.38^{* * *} \\
(2.76)\end{array}$ \\
\hline Wage Coordination & $\begin{array}{c}1.96^{* * *} \\
(.42)\end{array}$ & $\begin{array}{c}3.33^{* * *} \\
(.57)\end{array}$ & $\begin{array}{c}3.55^{* * *} \\
(.64)\end{array}$ \\
\hline $\begin{array}{l}\text { Electoral } \\
\text { Participation }\end{array}$ & $\begin{array}{c}-.19^{* * *} \\
(.04)\end{array}$ & $\begin{array}{c}-.24^{\star \star *} \\
(.06)\end{array}$ & $\begin{array}{c}-.25^{\star \star \star} \\
(.05)\end{array}$ \\
\hline $\begin{array}{l}\text { Demographic } \\
\text { Burden }\end{array}$ & $\begin{array}{l}1.83^{* * *} \\
(.14)\end{array}$ & $\begin{array}{c}1.75^{* * *} \\
(.16)\end{array}$ & $\begin{array}{c}1.76^{\star \star \star} \\
(.15)\end{array}$ \\
\hline $\begin{array}{l}\text { Generosity of } \\
\text { Welfare Programs }\end{array}$ & $\begin{array}{l}.18^{* * *} \\
(.01)\end{array}$ & $\begin{array}{l}.15^{* * *} \\
(.01)\end{array}$ & $\begin{array}{l}.15^{* * *} \\
(.01)\end{array}$ \\
\hline Constant & $\begin{array}{c}.25 \\
(5.44) \\
\end{array}$ & $\begin{array}{l}-1.97 \\
(5.33)\end{array}$ & $\begin{array}{c}.18 \\
(5.47)\end{array}$ \\
\hline$R^{2}$ & .924 & .850 & .858 \\
\hline $\begin{array}{l}\text { Observations } \\
\text { Countries } \\
\text { Time units }\end{array}$ & $\begin{array}{l}84 \\
14 \\
6\end{array}$ & $\begin{array}{c}84 \\
14 \\
6\end{array}$ & $\begin{array}{c}78 \\
13 \\
6\end{array}$ \\
\hline $\begin{array}{l}\text { LM Test: serial } \\
\text { correlation, } p \text {-value }\end{array}$ & .106 & $.040^{\star *}$ & $.046^{\star \star}$ \\
\hline
\end{tabular}

Panel-corrected standard errors in parentheses

Significance level: ${ }^{*}<.10,{ }^{* *} p<.05 ;{ }^{* * *} p<.01$

Lagrange Multiplier test $p$-value below .05 rejects the absence of serial correlation at $95 \%$ confidence interval 
Table 5

Panel a

Labor AETR Under Unified Government

Predicted Levels of AETR on Labor Income

Given Partisan Situation and Institutional Context.

\begin{tabular}{|c|c|c|c|c|}
\hline & $\begin{array}{l}\text { Weak } \\
\text { Executive }\end{array}$ & & $\begin{array}{l}\text { Strong } \\
\text { Executive }\end{array}$ & \\
\hline & $\begin{array}{c}\text { Left } \\
\text { Cabinet-Left } \\
\text { Parliament }\end{array}$ & $\begin{array}{c}\text { Right } \\
\text { Cabinet- } \\
\text { Right } \\
\text { Parliament }\end{array}$ & $\begin{array}{c}\text { Left } \\
\text { Cabinet-Left } \\
\text { Parliament }\end{array}$ & $\begin{array}{c}\text { Right } \\
\text { Cabinet- } \\
\text { Right } \\
\text { Parliament }\end{array}$ \\
\hline $\begin{array}{c}\text { Mendoza, et } \\
\text { al }\end{array}$ & 38.9 & 27.3 & 32.4 & 30.8 \\
\hline $\begin{array}{c}\text { OECD } \\
\text { version } 1\end{array}$ & 36.1 & 19.9 & 33.2 & 28.7 \\
\hline $\begin{array}{c}\text { OECD } \\
\text { version } 2\end{array}$ & 37.9 & 22.2 & 34.6 & 31.0 \\
\hline
\end{tabular}

Partisan and institutional terms set at mean $+/-1$ standard deviation.

All other factors set to their mean values.

Panel b

Labor AETR Under Divided Government

Predicted Levels of AETR on Labor Income

Given Partisan Situation and Institutional Context

\begin{tabular}{|c|c|c|c|c|}
\hline & $\begin{array}{l}\text { Weak } \\
\text { Executive }\end{array}$ & & $\begin{array}{l}\text { Strong } \\
\text { Executive }\end{array}$ & \\
\hline & $\begin{array}{c}\text { Left } \\
\text { Cabinet- } \\
\text { Right } \\
\text { Parliament }\end{array}$ & $\begin{array}{c}\text { Right } \\
\text { Cabinet-Left } \\
\text { Parliament }\end{array}$ & $\begin{array}{c}\text { Left } \\
\text { Cabinet- } \\
\text { Right } \\
\text { Parliament }\end{array}$ & $\begin{array}{c}\text { Right } \\
\text { Cabinet-Left } \\
\text { Parliament }\end{array}$ \\
\hline $\begin{array}{l}\text { Mendoza, et } \\
\text { al }\end{array}$ & 29.2 & 37.0 & 32.7 & 30.5 \\
\hline $\begin{array}{l}\text { OECD } \\
\text { version } 1\end{array}$ & 22.2 & 33.8 & 31.0 & 30.9 \\
\hline $\begin{array}{l}\text { OECD } \\
\text { version } 2\end{array}$ & 24.6 & 35.5 & 33.4 & 32.2 \\
\hline
\end{tabular}

Partisan and institutional terms set at mean $+/-1$ standard deviation. All other factors set to their mean values. 
The situation of divided government is illustrated in the panel $b$ of Table 5. On the left hand side we have a political configuration where the executive is weak (i.e., the legislature is the dominant institution) and the two institutions have different ideological orientations. The lack of unity in terms of ideological orientation does not seem to matter greatly. Once again, where the legislature is the dominant institution, the pronounced difference in policy outcome, given the different ideological orientations, comes through. And, again, it is muted in the situation described on the opposite side of the panel, where the executive is the dominant institution.

In sum, then, partisanship works its effect on labor income tax policy. However, these partisan effects are either moderated or amplified by the institutional context within which political parties operate. Of particular importance are the relative strengths of the executive and legislature. Where the executive is more powerful, the force of partisanship is evident but very dampened. Such institutional settings are common to electoral systems based on majoritarian principles. These systems encourage moderation in policy since the leverage they give to the median voter facilitates the muting of partisan differences. This muting effect is absent in institutional settings where the legislature is the dominant branch. Such an institutional setting is found in systems regulated by electoral rules that promote proportionality. Here partisan effects are stark in manifesting themselves and here again we see that the left fosters much higher average effective tax rates on labor income than does the right.

Ideological orientations of parties, the relative strength of governmental institutions, and the degree of wage coordination within the economy: what is it about this set of factors that brings them together to shape tax strategy on labor income? They are related not only in that they influence this strategy but also in that they are important features of Coordinated Market and Liberal Market Economies.

Countries with higher levels of wage coordination, i.e., Coordinated Market Economies, are more likely to have left-wing governments and strong legislatures. Such a pattern speaks to the notion of institutional complementarities as reinforcing mechanisms for the differences between LMEs and CMEs. Two institutions are said to be complementary "if the presence (or efficiency) of one increases the returns from (or efficiency of) the other" (Hall and Soskice 2001:17). In particular, two types of complementarities are relevant to our concerns.

The first of these complementarities is between economic and formal political institutions. The long-term functioning of wage coordination agreements requires risky investments by both workers and employers. As a result, the latter "cannot go down the route [of risky investments] unless they can be sure the government will sustain it" (Gourevitch and Haves 2002: 245-247).

Belief in a government's commitment to existing policy is more likely in those political systems where actors have a better chance to 
punish government if it deviates from that commitment. Hall and Soskice (2001) contend that systems based on proportional representation are better than majoritarian systems in providing actors with this monitoring and control capacity over government. In majoritarian systems a small shift in the distribution of votes theoretically could lead to a large shift in policy. In proportional representation systems, such changes are uncommon. There the legislature is stronger vis-à-vis the executive and coalition governments are more common. In such a context, parties defending the interests of specific economic actors have a better chance to punish the government if it deviates from previous policy. As a result, government commitments are more credible in proportional systems, and this facilitates the long-term functioning of economic institutions.

Gourevitch and Haves (2002: 246) show that there is indeed a strong positive correlation between the economic institutions of CMEs and the presence of proportional representation $(r=0.71)$ and coalition governments $(r=0.72)$. Using the Lijphart data on legislative dominance and Hall and Gingerich's index of overall coordination in the economy (see Figure 7), this point is reinforced. In sum, the presence of strong legislatures in CMEs facilitates the sustainability of wage coordination agreements and, in turn, the adoption of a particular taxation strategy.

\section{Figure 7}

Coordination and Legislative Dominance

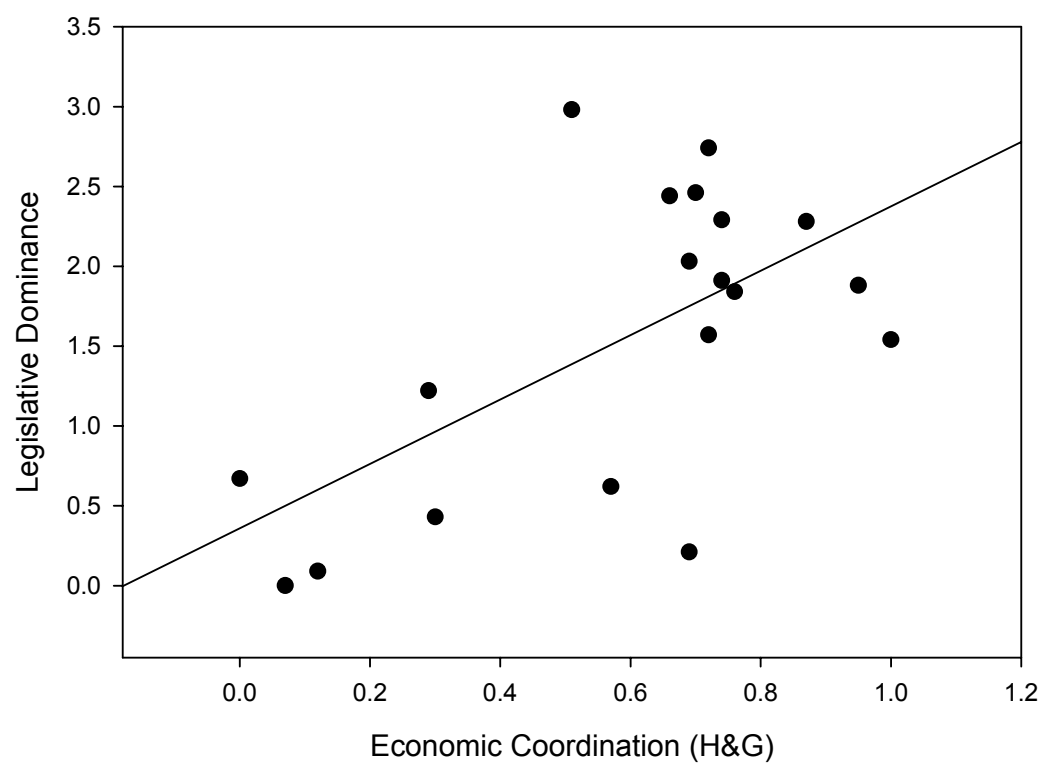

The second of these complementarities is to be found within the political realm, namely, that between the electoral system and the partisan composition of the government. As Iversen and Soskice (2002) have pointed out, the coexistence of strong legislatures and left-wing governments is no coincidence. They are both associated with electoral systems that use proportional representation. In proportional representation systems, middle class parties need to compromise with 
other parties to govern. Iversen and Soskice (2002) show that it is in the interest of center parties to coalesce with the left because the type of redistribution policy provided by a center-left government would be closer to the center's preferences than the redistribution policy that a center-right coalition would provide. As a result, countries with strong legislative institutions are more likely to have left-wing governments, which in turn reinforces a model of redistribution based on a large welfare state and high tax rates on labor.

In conclusion, this section has highlighted the mechanisms that explain why CMEs tend to show higher tax rates on labor. They do so because they have higher levels of wage coordination, their governments are more likely to be oriented to the left, and their executives are relatively weak in relation to their legislatures. The question now remains as to the consequences of a strategy based on high taxes on labor for the performance of national economies. We turn to this issue in the final section of the paper.

\section{Tax Strategies and Labor Market Performance}

In practice, tax strategies are not economically neutral. They have consequences for the working of different markets and the economy in general. In this section we analyze whether or not and how the specific taxation strategies developed by CMEs affect the working of the economy. In order to do so, we concentrate on the relation between labor taxation and unemployment.

Standard models in labor economics contend that strategies based on high levels of labor income taxation come at the price of increasing the levels of unemployment. This prediction is based on the analysis of the effects of labor income taxation on the supply and demand of labor. More specifically, these models point out three main causal mechanisms in this relation.

First and foremost, higher taxes on labor income increase the price of labor and thereby reduce the demand for it. The effect of the increase in the price of labor depends on the extent to which employers bear the costs of higher levels of labor taxation. The operating mechanism through which higher taxes reduce labor demand is the adjustment of gross wages to labor tax increases. Higher taxes on labor are translated into higher gross wages in order to maintain workers' real wages (Daveri and Tabellini 2000: 57-62). As a result of this translation the price of labor increases and the demand for it declines.

Second, labor taxes may affect unemployment through their interplay with labor supply decisions. "Textbook" models reveal two possible effects of labor taxes (Atkinson 1993: 20-50) on labor supply. The first is an income effect: taxes make people worse off by reducing their disposable income (in technical terms, the indifference curve between 
work and leisure is shifted downwards). In these circumstances, the number of hours worked is increased in order to maintain the level of disposable income. The second effect is one of substitution: labor taxes increase the opportunity cost of work in terms of leisure (in technical terms, they create movements along the indifference curve between work and leisure). As a result, an increase in labor taxes leads people to reduce the number of hours they are willing to work. In principle, the income effect is likely to dominate in the bottom part of the distribution of earnings, working to increase labor supply. In the case of low-income earners, higher labor taxes would provoke, simultaneously, an increase in labor supply and a reduction in labor demand. The net result is an increase in the incidence of unemployment in this group.

Finally, the interaction between labor taxes and transfers may add to unemployment through a different causal logic (Nickell and Layard 1999; Disney 2000). A lower number of working hours (at the extreme, 0) plus income transfers or subsidies may generate disposable income higher than that obtained by someone working more hours (and therefore being taxed more) and receiving less transfers or subsidies. Under these conditions, higher labor taxes will create incentives for some people to either enter into or remain within the state of unemployment (Joumard 2001).

As a result of these three mechanisms, higher rates of taxation on labor income are expected to generate higher levels of unemployment. Despite its compelling logic, the validity of this argument is open to an important qualification. A fundamental assumption in these models is that actors make their decisions in a world free of institutions. Yet, if such an assumption is relaxed, there are reasons to believe that the arrangements between capital and labor at work in CMEs shape the effects of labor taxes on the unemployment rate (Daveri and Tabellini 2000).

This brings us back to the arrangements between capital and labor at work in CMEs. As argued above, CMEs are organized around a fundamental agreement between capital and labor. Employers trade their acceptance of the development of a large public insurance system for a commitment from the unions to wage moderation. If, as a result of the incidence of labor taxes and the high levels of generosity, labor costs increased dramatically, the incentives of employers to coordinate with the unions would disappear. Thus, the capacity of unions to shift onto employers the cost of labor taxes via the adjustment of gross wages is heavily constrained in CMEs as opposed to LMEs. As a result, in those economies with high levels of coordination(CMEs), the effects of labor taxes on labor demand and, ultimately, on the unemployment rate are expected to be muted. On the contrary, labor taxes are expected to have a larger incidence on unemployment in LMEs.

In the following we set out to test the claim that the impact of labor taxes on the levels of unemployment is contingent upon the levels of coordination in the labor market. Our specification of the relation between taxes on labor and unemployment relates to previous contributions in 
several respects. First, we do not assume the existence of a direct causal link between certain economic or political institutions and the unemployment rate. ${ }^{18}$ Rather, we contend that institutions such as wage coordination affect the way in which policy instruments (e.g., labor taxes) generate direct behavioral responses on the part of workers and employers. Second, we follow the approach of Daveri and Tabellini (2000) to capture the effects of interest, albeit using a different indicator of coordination. We interact two continuous variables, namely the average effective tax rates on labor and the index of wage bargaining coordination computed by Kenworthy. The coordination index has been rearranged to rank between 1 (maximum level of coordination) and 5 (minimum level of coordination) and multiplied thereafter by the average effective tax rates on labor. In this way, there is no need to introduce a constituent term for labor taxation in the specification: when there is no coordination, the coefficient of the interaction is capturing the impact of labor taxation on unemployment. Nor have we included a constituent term for wage coordination. The use of an independent term for wage coordination would require one to assume that some governments in our sample exempt labor from being taxed at all. This seems unreasonable.

Before describing our estimates of the effects of labor tax rates on unemployment, let us deal with the other influences in the model. First, we control for the effects of inertia in the aggregate level of unemployment by including the lagged dependent variable. Second, a measure of aggregate world demand intended to control for changes in the economic situation of each country 's major trading partners (Alt 1985) is included in the model. The intuition behind this variable is that if the major trading partners of a country experience economic downturns, this will reduce the demand for products from these countries, which in turn contracts labor demand and increases unemployment. Because of the way this variable is operationalized (see Table 6), we expect it to have a positive association with the unemployment rate. In addition, an indicator of the overall generosity of unemployment benefits (defined as the product of the level of benefits and their duration) is added to the model (see Table 6). This variable introduces a control for the behavioral responses that public transfers generate in the labor market. The logic underpinning this variable is that a more generous benefits system increases the reservation wage and makes the levels of unemployment higher and spells longer. Thus, a positive relation between the generosity index and the unemployment rate is expected. Finally, because of their alleged potential effects on labor demand (Scharpf 2000: 75-82), we also include as controls other significant elements of the tax system, namely the effective tax rates on consumption, capital, and corporate income. The relation between these variables has been specified using a panel regression equation using data on 13 OECD countries for five five-year periods.

$$
\begin{gathered}
U_{i t}=\alpha+\beta_{1} U_{i t-1}+\beta_{2} B R R_{i t} * B D_{i t}+\beta_{3} W D_{i t} \\
+\gamma_{1} L T R_{i t} * L W C_{i t}+\gamma_{2} \text { KTR }_{i t}+\gamma_{3} \operatorname{CORTR}_{i t}+\gamma_{4} \operatorname{CONTR}_{i t}+\varepsilon_{i t}
\end{gathered}
$$

\footnotetext{
${ }^{18}$ See, e.g., Hall and Franzese 1998; Iversen; 1998,1999, 2000; Soskice and Iversen,
} 2000; and Franzese 2002b. 
Table 6 below provides the definitions for the variables in the equation. Estimation results using OLS with panel corrected standard errors (Beck and Katz 1995, 1996) are reported in Table $7^{19}$. As in the previous section, the equation has been estimated three times, once using the Mendoza tax rates and then with the two variants of the OECD rates. ${ }^{20}$

The goodness of the fit is similar in all three equations. Substantively and statistically the results are very similar for the three versions of the labor tax rates. The exceptions deal with the impacts of the tax rates on capital and corporate income. Although capital tax rates show no statistically significant effects, the sign of the coefficient for this variable varies depending on the tax rates being used. In turn, corporate tax rates show very consistent and significant effects on the unemployment rate. In commenting on the other parameter estimates we will concentrate on those parameter values produced using the Mendoza series.

Higher values on the world demand index, which signify declines in demand from major trading partners, are reflected in higher levels of unemployment. In addition, the effects of the overall generosity of unemployment benefits have the positive impact anticipated. Moreover, our findings are consistent with the claim that increasing the tax rate on corporations reduces labor demand and drives unemployment upwards.

Finally the results support our claim that the unemployment consequences of labor taxes are contingent on the degree of wage bargaining coordination. By way of illustration, suppose that the tax rate on labor income increases by one standard deviation, which in our sample implies that taxes on labor increase by 10.5 percent. Using the estimates reported in the first column of Table 7 , we can assess how such an increase affects the level of unemployment under different institutional conditions. In those countries where there is no coordination between capital and labor $(\mathrm{LWC}=5)$, the unemployment rate will rise by 8.4 percent. If wage coordination were at a moderate level $(L W C=3)$, the increase in the unemployment rate would be 5 percent. Finally, in those nations where the coordination between capital and labor is at its peak $(L W C=1)$, a 10.5 percent increase in labor tax rates will entail an increase of only 1.7 percent in the unemployment rate.

\footnotetext{
${ }^{19}$ The equation has also been estimated using as endogenous variables the OECD standardized unemployment rate (Nickell and Nunziata 2001) and the OECD time variant NAIRU estimates (Turner, et al (2001)). The results are similar to those reported in Table 7.Our thanks to Peter Richardson for providing us with the NAIRU series.

${ }^{20}$ Note that missing data problems for one of the OECD variants reduced the number of countries to thirteen: Australia, Austria, Belgium, Canada, Finland, France, Germany, Italy, Japan, Netherlands, Sweden, United Kingdom, and the United States.
} 
Table 6

Variables in Models Predicting the Unemployment Rate

\begin{tabular}{|c|c|}
\hline $\begin{array}{l}\text { Variable } \\
\text { Label }\end{array}$ & Variable definition. \\
\hline$U_{i t}$ & $\begin{array}{l}\text { Rate of unemployment. Data are based on national definitions } \\
\text { drawn from various annual volumes of the OECD's Labour } \\
\text { Force Statistics. }\end{array}$ \\
\hline$U_{i t-1}$ & Lagged level in the rate of unemployment in use. \\
\hline$L W C_{i t}$ & $\begin{array}{l}\text { Lack of Wage Bargaining Coordination. It is a transformation } \\
\text { (LoWC=6-WC) of Kenworthy's wage coordination index (WC), } \\
\text { period average. }\end{array}$ \\
\hline$B R R_{i t}$ & $\begin{array}{l}\text { Benefit Replacement Rate data provided by the OECD. The } \\
\text { data refers to the first year of unemployment benefits, } \\
\text { averaged over family types of recipients. The benefits are a } \\
\text { percentage of average earnings before tax. See Nickell and } \\
\text { Nunziata (2001) for details. }\end{array}$ \\
\hline$B D_{i t}$ & $\begin{array}{l}\text { Benefit Duration Index was developed by Wolfers (1999). The } \\
\text { index is constructed in such a way that its value is } 1 \text { (if the } \\
\text { benefit provision in the first year remains the same through the } \\
\text { first four years) or between } 0 \text { and } 1 \text { (if otherwise). See Nickell } \\
\text { and Nunziata (2001) for details. }\end{array}$ \\
\hline$W D_{i t}$ & $\begin{array}{l}\text { Alt's world aggregate demand measure. Sum of weighted } \\
\text { unemployment rates }(U) \text { in major trading partners. Weights are } \\
\text { based on relative size of trading partners' shares of exports }(X) \\
\text { from country } m^{21} \text { In addition to the thirteen countries } \\
\text { mentioned in an earlier footnote, six other countries are } \\
\text { included in these calculations; these are: Denmark, Greece, } \\
\text { Ireland, Norway, Portugal and Spain. }\end{array}$ \\
\hline$L T R_{i t}$ & $\begin{array}{l}\text { Average effective tax rate on labor income. Three variants from } \\
\text { Mendoza, et al and the OECD. See Table } 4 \text { for sources. }\end{array}$ \\
\hline$K_{T R}$ & Average effective tax rate on capital income. \\
\hline CORTR $_{i t}$ & Average effective tax rate on corporate profits. \\
\hline$C O N T R_{i t}$ & Average effective tax rate on consumption. \\
\hline
\end{tabular}

${ }^{21}$ The formula for James Alt's (1985) World Demand index is :

$W_{m}=\sum\left(X_{i} / \sum X_{j}\right) U i$, where $: i, j \neq m$.

Note that the trade data are derived from Kristian S. Gelditsch's Expanded Trade and GDP Data Set, Version 2.1. This is available at http://weber.ucsd.edu/ kgledits/exptradegdp.html 
Table 7

Panel Estimation Results for Model Predicting the Unemployment Rate: National Definitions (5 year averages)

\begin{tabular}{|c|c|c|c|}
\hline AETR Definition: & Mendoza & OECD 1 & OECD 2 \\
\hline $\begin{array}{l}\text { Lagged } \\
\text { Unemployment Rate, National } \\
\text { Definition }\end{array}$ & $\begin{array}{l}.609 * * * \\
(.126)\end{array}$ & $\begin{array}{l}.634^{* * *} \\
(.116)\end{array}$ & $\begin{array}{l}675^{* * *} \\
(.113)\end{array}$ \\
\hline $\begin{array}{l}\text { AETR Labor * Lack of Wage Bargaining } \\
\text { Coordination }\end{array}$ & $\begin{array}{l}.016^{\star * *} \\
(.006)\end{array}$ & $\begin{array}{l}.015^{* *} \\
(.007)\end{array}$ & $\begin{array}{l}.013^{*} \\
(.007)\end{array}$ \\
\hline Benefit Replacement Rate* Benefit Duration & $\begin{array}{l}5.54^{* * *} \\
(2.00)\end{array}$ & $\begin{array}{c}5.31^{* * *} \\
(2.08)\end{array}$ & $\begin{array}{l}4.50^{* *} \\
(1.97) \\
\end{array}$ \\
\hline Alt's World Demand & $\begin{array}{l}.206^{*} \\
(.114)\end{array}$ & $\begin{array}{l}.281^{* *} \\
(.116)\end{array}$ & $\begin{array}{l}.207^{*} \\
(122)\end{array}$ \\
\hline AETR Consumption & $\begin{array}{l}-.036 \\
(.050) \\
\end{array}$ & $\begin{array}{l}-.068 \\
(.076) \\
\end{array}$ & $\begin{array}{l}-.029 \\
(.085) \\
\end{array}$ \\
\hline AETR Capital & $\begin{array}{c}.003 \\
(.018)\end{array}$ & $\begin{array}{l}-.027 \\
(.021)\end{array}$ & $\begin{array}{c}.000 \\
(.019)\end{array}$ \\
\hline AETR Corporate & $\begin{array}{l}.028^{* * *} \\
(.011) \\
\end{array}$ & $\begin{array}{l}.023^{* * *} \\
(.007) \\
\end{array}$ & $\begin{array}{l}.018^{* *} \\
(.009) \\
\end{array}$ \\
\hline Constant & $\begin{array}{l}1.07 \\
(.728)\end{array}$ & $\begin{array}{l}-.142 \\
(.802)\end{array}$ & $\begin{array}{c}-.82 \\
(1.11)\end{array}$ \\
\hline$R^{2}$ & .81 & .81 & .80 \\
\hline $\begin{array}{l}\text { Observations } \\
\text { Countries } \\
\text { Time units } \\
\end{array}$ & $\begin{array}{c}65 \\
13 \\
5 \\
\end{array}$ & $\begin{array}{c}65 \\
13 \\
5 \\
\end{array}$ & $\begin{array}{c}65 \\
13 \\
5 \\
\end{array}$ \\
\hline LM test for serial correlation, $p$-value & .389 & .335 & .279 \\
\hline
\end{tabular}




\section{CONCLUSION}

The paper has examined how the tax regimes across the OECD countries developed in the latter part of the $20^{\text {th }}$ century. It has given particular emphasis to tax on labor income, which have become an important fiscal instrument. A number of results emerge from this examination. First, not only do labor income taxes represent a major drain on private households; they have become the mainstay of many of these countries' public sector finances.

Second, these taxes, and not taxes on capital, appear to be the preferred instrument of finance for those economic and political interests that advocate and support a strong (and thereby expensive) welfare state. We have been able to show that leftist parties, particularly in political systems where legislatures dominate the executive, push for higher taxes on labor with the apparent motive of helping to finance welfare spending. By pursuing this kind of tax strategy there is little "free lunch" to be had in these welfare states. What the working class receives, the working class pays for. Capital is little burdened by the welfare state and, indeed, in those economies that enjoy a high degree of coordination (particularly in terms of wage bargaining) one can say capital is being subsidized by affording it favorable labor market conditions (e.g., skilled labor that has strong incentives to remain loyal to employers and make moderate wage demands).

Third, the effort at financing the welfare state this way comes at a cost in terms of lost employment opportunities. However, the magnitude of this loss is itself a function of the institutional conditions in the labor market. The recent results presented by Peter Lindert (2003) on the kind of taxation strategy we have described here suggest that there are beneficial qualities to such a strategy, at least in terms of overall economic growth. In addition, our results suggest that wherever labor and capital are able to coordinate, the employment costs of taxing work are significantly reduced. 


\section{References}

Alt, James (1985) "Political Parties, World Demand, and Unemployment: Domestic and International Sources of Economic Activity," American Political Science Review 79: 1016-1040.

Atkinson, Anthony (1993) "Work Incentives". In Anthony Atkinson and Gunnar Viby Mogensen, eds., Welfare and Work Incentives. Oxford: Clarendon Press.

Atkinson, Anthony and Joseph Stiglitz (1980) Lectures in Public Economics, New York: Mc-Graw Hill.

Austen-Smith, David and Jeffrey Banks (1988) "Elections, Coalitions and Legislative Outcomes" American Political Science Review 82/2: 405-422.

Bartels, Larry M. (2003) Partisan Politics and the U.S. Income Distribution." Mimeo, Department of Political Science and Woodrow Wilson School of Public and International Affairs, Princeton University.

Bean, Charles (1994) "European Unemployment: A Survey," Journal of Economic Literature 32/2: 573-619.

Beck, Nathaniel and Jonathan Katz (1995) "What to Do (and Not to Do) with Time-Series-Cross-Section Data," American Political Science Review 89:634-647.

Beck, Nathaniel and Jonathan Katz (1996) "Nuisance vs. Substance: Specifying and Estimating Time-Series-Cross-Section Models." In John R. Freeman, ed., Political Analysis, Volume 6, Ann Arbor: University of Michigan Press.

Blais, A., Donald Blake and Stépane Dion (1993). "Do Parties Make a Difference? Parties and the Size of Government in Liberal Democracies," American Journal of Political Science 37/1: 40-62.

Boix, Carles (1999) Political Parties, Growth and Equality: Conservative and Social Democratic Strategies in the World Economy. Cambridge: Cambridge University Press.

Boadway R. and M. Keen (2000), "Redistribution." In A. Atkinson and F. Bourguignon, eds., Handbook of Income Distribution. Oxford: Elsevier.

Bretscher, Lucas and Frank Hettich (2002) Globalization, Capital Mobility and Tax Competition. Theory and Evidence for OECD Countries," European Journal of Political Economy 18/4: 695-716.

Cameron David (1984) "Social Democracy, Corporatism, Labor Quiescence, and the Representation of Economic Interests in Advanced Capitalist Society." In John Goldthorpe, ed., Order and Conflict in Contemporary Capitalism, London, Oxford University Press. 
Carey, David and Harry Tchilinguirian (2000) "Average Effective Rates on Capital, Labour and Consumption," Economics Department, Working Paper No. 205. Paris, OECD.

Coe D.T. and D.J. Snower (1997) "Policy Complementarities: the Case for Labor Market Reform," IMF Staff Papers, 44/1: 1-35.

Cox, Gary W. (1997) Making Votes Count. Cambridge, Cambridge University Press

Cusack, Thomas R. (1997) "Partisan Politics and Public Finance," Public Choice, 91/3-4: 375-395.

Cusack, Thomas R. and Susanne Fuchs (2003) "Parteinen, Institutionen und Staatsausgaben." In Herbert Obinger, Uwe Wagschal, and Bernhard Kittel, eds., Politische Ökonomie: Demokratie und wirtschaftliche Leistungsfähigkeit. Leverkusen: Leske and Budrich.

Daveri, Francesco and Guido Tabellini (2000) "Unemployment and Taxes," Economic Policy 30: 49-89.

Disney, R. (2000) "The Impact of Tax and Welfare Policies on Employment and Unemployment in OECD Countries," IMF Working Papers 00/164.

Duverger, Maurice (1954) Political Parties. New York: Wiley

Esping-Andersen, Gosta (1985) Politics against Markets Princeton, Princeton University Press

Estevez-Abe, Margarita, Torben Iversen and David Soskice (2001) "Social Protection and the Formation of Skills: a Reinterpretation of the Welfare State." In Peter Hall and David Soskice, eds., Varieties of Capitalism, Oxford, Oxford University Press.

Eurostat (2000) Structures of the Taxation Systems in the European Union 1970-1997. Luxembourg: Office for Official Publications of the European Communities.

Franzese, Robert J. Jr. (2000) "Political Participation, Income Distribution, and Public Transfers in Developed Democracies," Department of Political Science, University of Michigan, Unpublished Manuscript.

Franzese, Robert J. Jr. (2002) "Electoral and Partisan Cycles in Economic Policies and Outcomes." In Nelson W. Polsby, ed., Annual Review of Political Science. Vol. 5. Palo Alto: Annual Reviews, pp. 369-422.

Franzese, Robert J. Jr. (2002b) Macroeconomic Policies of Developed Democracies. Cambridge: Cambridge University Press. 
Ganghof, Steffen (2002) "Veto Points and Veto Players: A Skeptical View," Paper presented at the Conference on The Consequences of Political Institutions in Democracy, Duke University, April 5-7, 2002.

Ganghof Steffen (2003) Parties, Power and Progressivity. On the Political Economy of Income Taxation in Open States. Ph.D. Thesis, Max Planck Institute for the Study of Societies, Köln

Genschel, Philipp (2002) "Globalization, Tax Competition and the Welfare State," Politics and Society, 30/2: 245-275

Gleditsch, Kristian S. (2002) "Expanded Trade and GDP Data," Journal of Conflict Resolution 46:712-24.

Gourevitch, Peter and Michael Haves (2002) "The Politics of Choice among National Production Systems", L’Année de la Régulation 6: 241270.

Hall, Peter and Robert J. Franzese Jr. (1998) "Mixed Signals: Central Bank Independence, Coordinated Wage Bargaining, and European Monetary Union", International Organization 52/3: 505-535.

Hall, Peter and David Soskice (2001) "Introduction." In Peter Hall and David Soskice, eds., Varieties of Capitalism, Oxford, Oxford University Press, 2001.

Hibbs, Douglas A. (1992). "Partisan Theory after Fifteen Years," European Journal of Political Economy 8: 8361-373.

Imbeau, Louis M., Francois Petry and Moktar Lamari (2001) "Left-Right Party Ideology and Government Policies: A Meta-Analysis," European Journal of Political Science 40:1-29.

Iversen, Torben (1998) "Wage Bargaining, Central Bank Independence and the Real Effects of Money," International Organization 52: 469-504.

Iversen, Torben (1999) Contested Economic Institutions: The Politics of Wage Bargaining in Advance Democracies. Cambridge: Cambridege University Press.

Iversen, Torben (2000) "Decentralization, Monetarism, and the Social Democratic Welfare State." In Tobben Iversen, Jonas Pontusson, and David Soskice, eds., Unions, Employers, and Central Banks:

Macroeconomic Coordination and Institutional Change in Social Market Economies. Cambridge: Cambridge University Press, 205-231.

Iversen, Torben and David Soskice (2001) "An Assets Theory of Social Policy Preferences," American Political Science Review, 95/4: 875-895.

Joumard, I. (2001) "Tax Systems in European Union Countries," OECD, Economics Department Working Paper \#301. 
Kenworthy, Lane (2001) "Wage-Setting Measures: A Survey and Assessment," World Politics 54:57-98. Date set available at http://www.emory.edu/SOC/lkenworthy.

Lindert, Peter (2003) Why the Welfare State Looks Like a Free Lunch." NBER Working Paper 9869.

Lijphart, Arend (1999) Patterns of Democracy: Government Forms and Performance in Thirty-Six Countries. New Haven: Yale University.

Martinez-Mongay, Carlos (2000) "ECFIN's Effective Tax Rates: Properties and Comparisons with other Tax Indicators." Directorate for Economic and Financial Affairs, European Commision, Economic Papers Number 146.

Mendoza, Enrique, Assaf Razin and Linda L. Tesar (1994) "Effective Tax Rates in Macroeconomics: Cross-Country Estimates of Tax Rates on Factor Incomes and Consumption," Journal of Monetary Economics 34/3: 297-323.

Nickell, Stephen and Richard Layard (1999) "Labor Market Institutions and Economic Performance". In Orley Ashenfelter and David Card, eds., Handbook of Labor Economics, vol 3, Amsterdam: Elsevier.

Nickell, Stephen and Luca Nunziata 2001, Labor Market Institutions Database, Mimeo, Nuffield College, Oxford University.

Obinger, Herbert and Uwe Wagschal (20039 „Parteien, Institutionen und Wohlfahrtstaat." In Herbert Obinger, Uwe Wagschal, and Bernhard Kittel, eds., Politische Ökonomie: Demokratie und wirtschaftliche Leistungsfähigkeit. Leverkusen: Leske and Budrich.

OECD (1998) Benefit Systems and Work Incentives. Paris: OECD.

OECD (2000) Taxing Wages. Income Tax, Social Security Contributions and Cash Family Benefits. OECD, Paris.

OECD (various years) National Accounts of OECD Countries, Detailed Tables, Volume II Paris: OECD.

OECD (various years) Labour Force Statistics. Paris: OECD.

OECD (various years) Revenue Statistics. Paris: OECD.

Regini M. (1984) "The Conditions for Political Exchange: How Concertation Emerged and Collapsed in Britain and Italy." In John Goldthorpe, ed., Order and Conflict in Contemporary Capitalism, London, Oxford University Press.

Schrarpf, Fritz W. (2000) "Economic Changes, Vulnerabilities and Institutional Capabilities." In Fritz W. Scharpf and Vivien A. Schmidt, eds., 
Welfare and Work in the Open Economy: From Vulnerability to Competitiveness, Oxford: Oxford University Press.

Schmidt, Manfred G. (1996). "When Parties Matter: A Review of the Possibilities and Limits of Partisan Influence on Public Policy," European Journal of Political Research 30: 155-183.

Schmidt, Manfred G. (2000) Demokratietheorien. 3rd Edition. Leverkusen: Leske and Budrich.

Schmidt, Manfred G. (2002). "The Impact of Political Parties, Constitutional Structures and Veto Players on Public Policy." In Hans Keman, ed., Comparative Democratic Politics. London, Sage: 166-184.

Soskice, David and Torben Iversen (2000) "The Nonneutrality of Monetary Policy with Large Price or Wage Setters." Quarterly Journal of Economics 115/1:365-284.

Steinmo, Swen (1993) Taxation and Democracy. New Haven: Yale University Press.

Swank, Dwain and Sven Steinmo (2002) "The New Political Economy of Taxation in Advanced Capitalist Democracies," American Journal of Political Science 46:642-655.

Swenson, Peter and Jonas Pontusson (2000) "The Swedish Employer Offensive against Centralized Bargaining." In Torben Iversen, Jonas Pontusson and David Soskice eds.,Unions, Employers and Central Banks, Cambridge, Cambridge University Press.

Tsebelis, George (1995) "Decision Making in Political Systems: Veto Players in Presidentialism, Parliamentarism, Multicameralism, and Multipartyism," British Journal of Political Science 25:289-326.

Turner, David, Laurence Boone, Claudia Giorno, Mara Meacci, David Rae and Peter Richardson (2001) "Estimating the Structural Rate of Unemployment for the OECD Countries", OECD Economic Studies No. $33,2001 / 2,171-216$.

Volkerink, Bjorn and Jakob deHaan (2001) Tax Ratios: A Critical Survey. OECD Tax Policy Studies, No. 5. Paris: OECD.

Wallerstein, Michael, Miriam Golden and Peter Lange (1997) "Unions, Employers Associations and Wage-setting Institutions in Northern and Central Europe, 1950-1992," Industrial and Labor Relations Review, 50/3: 379-401.

Wallerstein, Michael and Miriam Golden (2000) "Postwar Wage Setting in the Nordic Countries." In Torben Iversen, Jonas Pontusson and David Soskice, eds., Unions, Employers and Central Banks. Cambridge: Cambridge University Press. 
Wolfers, Justin (1999) "Replacement Rates and Benefit Duration" Mimeo, Stanford Graduate School of Business. 

Bücher des Forschungsschwerpunkts Markt und politische Ökonomie

Books of the Research Area Markets and Political Economy

Sebastian Kessing

Essays on Employment Protection

2003, Freie Universität Berlin,

http://www.diss.fu-berlin.de/2003/202

Daniel Krähmer

On Learning and Information in Markets and

Organizations

2003, Shaker Verlag

Andreas Stephan

Essays on the Contribution of Public Infrastructure to Private: Production and its Political

Economy

2002, dissertation.de

Hans Mewis

Essays on Herd Behavior and Strategic

Delegation

2001, Shaker Verlag

Andreas Moerke

Organisationslernen über Netzwerke - Die personellen Verflechtungen von

Führungsgremien japanischer

Aktiengesellschaften

2001, Deutscher Universitäts-Verlag

Silke Neubauer

Multimarket Contact and Organizational Design

2001, Deutscher Universitäts-Verlag

Lars-Hendrik Röller, Christian Wey (Eds.)

Die Soziale Marktwirtschaft in der neuen

Weltwirtschaft, WZB Jahrbuch 2001

2001, edition sigma

Michael Tröge

Competition in Credit Markets: A Theoretic

Analysis

2001, Deutscher Universitäts-Verlag

Tobias Miarka

Financial Intermediation and Deregulation:

A Critical Analysis of Japanese Bank-Firm-

Relationships

2000, Physica-Verlag

Rita Zobel

Beschäftigungsveränderungen und organisationales Lernen in japanischen Industriengesellschaften

2000, Humboldt-Universität zu Berlin http://dochost.rz.hu-berlin.de/dissertationen/zobelrita-2000-06-19
Jos Jansen

Essays on Incentives in Regulation and

Innovation

2000, Tilburg University

Ralph Siebert

Innovation, Research Joint Ventures, and Multiproduct Competition

2000, Humboldt-Universität zu Berlin

http://dochost.rz.hu-berlin.de/dissertationen/siebertralph-2000-03-23/

Damien J. Neven, Lars-Hendrik Röller (Eds.)

The Political Economy of Industrial Policy in

Europe and the Member States

2000, edition sigma

Jianping Yang

Bankbeziehungen deutscher Unternehmen: Investitionsverhalten und Risikoanalyse

2000, Deutscher Universitäts-Verlag

Christoph Schenk

Cooperation between Competitors -

Subcontracting and the Influence of Information, Production and Capacity on Market Structure and Competition

1999, Humboldt-Universität zu Berlin

http://dochost.rz.hu-berlin.de/dissertationen/schenkchristoph-1999-11-16

Horst Albach, Ulrike Görtzen, Rita Zobel (Eds.)

Information Processing as a Competitive

Advantage of Japanese Firms

1999, edition sigma

Dieter Köster

Wettbewerb in Netzproduktmärkten

1999, Deutscher Universitäts-Verlag

Christian Wey

Marktorganisation durch Standardisierung: Ein

Beitrag zur Neuen Institutionenökonomik des

Marktes

1999, edition sigma

Horst Albach, Meinolf Dierkes, Ariane Berthoin Antal, Kristina Vaillant (Hg.)

Organisationslernen - institutionelle und

kulturelle Dimensionen

WZB-Jahrbuch 1998

1998, edition sigma 
Lars Bergman, Chris Doyle, Jordi Gual, Lars Hultkrantz, Damien Neven, Lars-Hendrik Röller, Leonard Waverman

Europe's Network Industries: Conflicting Priorities - Telecommunications

Monitoring European Deregulation 1

1998, Centre for Economic Policy Research

Manfred Fleischer

The Inefficiency Trap

Strategy Failure in the

German Machine Tool Industry

1997, edition sigma
Christian Göseke

Information Gathering and Dissemination

The Contribution of JETRO to

Japanese Competitiveness

1997, Deutscher Universitäts-Verlag 

Fredrik Andersson

Kai A. Konrad

Lars-Hendrik Röller

Christian Wey

Talat Mahmood Klaus Schömann

Talat Mahmood Klaus Schömann

Jos Jansen

Jos Jansen

Günter Franke Harris Schlesinger Richard C. Stapleton

Tomaso Duso

Johan Lagerlöf

Paul Heidhues

Olivier Cadot Lars-Hendrik Röller Andreas Stephan

Justus Haucap

Christian Wey

Heidrun C. Hoppe Emre Ozdenoren

Rainer Nitsche

Daniel Krähmer

J. Peter Murmann

Kai A. Konrad

Robert Nuscheler

Fredrik Andersson Kai A. Konrad
Human Capital Investment and Globalization in Extortionary States

Merger Control in the New Economy

Die Determinanten der Mirgrationsentscheidung von IT-Hochschulabsolventen aus Pakistan Empirische Befunde zur Ausgestaltung der deutschen „Green Card“

The Determinants of the Migration Decision of ITgraduates from Pakistan: Empirical Evidence for the Design of a German "Green Card"

The Effects of Disclosure Regulation on Innovative Firms: Common Values

The Effects of Disclosure Regulation on Innovative Firms: Private Values

Multiplicative Background Risk

On the Politics of the Regulatory Reform:

Econometric Evidence from the OECD Countries

On the Desirability of an Efficiency Defense in

Merger Control

Contribution to Productivity or Pork Barrel? The Two Faces of Infrastructure Investment

Unionization Structures and Firms' Incentives for Productivity Enhancing Investments

Intermediation in Innovation

On the Effectiveness of Anti-Predation Rules

Entry and Experimentation in

Oligopolistic Markets for Experience Goods

The Coevolution of Industries and National Institutions: Theory and Evidence

Terrorism and the State

Physician Reimbursement, Time-Consistency and the Quality of Care

Taxation and Education Investment in the Tertiary Sector
FS IV $02-06$

FS IV $02-11$

FS IV $02-12$

FS IV $02-15$

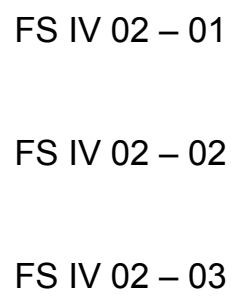

FS IV $02-02$ 
Jan Boone

Kai A. Konrad

Helmut Bester

Kai A. Konrad

Kjell Erik Lommerud Bjørn Sandvik

Odd Rune Straume

Steffen Huck Vicki Knoblauch Wieland Müller

Ralph Siebert

Jürgen Bracht

Saul Lach

Eyal Winter

Steffen Huck

Kai A. Konrad

Daniel Krähmer

Thomas Knaus

Robert Nuscheler

Kurt R. Brekke

Robert Nuscheler

Odd Rune Straume

Kai A. Konrad

Sebastian Kessing

Sebastian Kessing

Michal Grajek

Robert M. Adams Lars-Hendrik Röller

Robin C. Sickles

Tomaso Duso

Damien J. Neven Lars-Hendrik Röller

Tomaso Duso Astrid Jung
'Be nice, unless it pays to fight': A New Theory of

Price Determination with Implications for

Competition Policy

Altruism and Envy in Contests:

An Evolutionarily Stable Symbiosis

Delay in Contests

Good Jobs, Bad Jobs and Redistribution

On the Profitability of Collusion in Location Games

Learning by Doing and Multiproduction Effects over the Life Cycle: Evidence from the

Semiconductor Industry

Modeling Oligopolistic Price Adjustment in Micro

Level Panel Data

Strategic Trade Policy and the Home Bias in Firm

Ownership Structure

Delegation versus Authority

Incomplete Risk Adjustment and Adverse

Selection in the German Public Health Insurance System

Quality and Location Choices under Price

Regulation

Inverse Campaigning

A Note on the Determinants of Labour Share Movements

Employment Protection and Product Market Competition

Identification of Network Externalities in Markets for Non-Durables

Market Power in Outputs and Inputs: An Empirical Application to Banking

The Political Economy of European Merger Control: Evidence using Stock Market Data

Market Conduct and Endogenous Lobbying: Evidence from the U.S. Mobile Telecommunications Industry
FS IV $02-20$

FS IV $02-21$

FS IV $02-22$

FS IV $02-28$

FS IV $02-29$

FS IV $02-18$

FS IV $02-19$

FS IV $02-23$

FS IV $02-24$

FS IV $02-25$

FS IV $02-26$

FS IV $02-27$

FS IV $02-30$

FS IV $02-31$

FS IV $02-32$

FS IV $02-33$

FS IV $02-34$

FS IV $02-35$ 
Annette Boom

Kai A. Konrad Wolfram F. Richter

Stergios Skaperdas

Johan Lagerlöf

Roman Inderst

Christian Wey

Sebastian Kessing

Robert Nuscheler

Lars Frisell

Paul Heidhues Nicolas Melissas

Pablo Beramendi

Daniel Krähmer

Ralph Siebert

Vivek Ghosal

Vivek Ghosal

Andreas Blume

Paul Heidhues

Sebastian Kessing

Tomaso Duso Astrid Jung

Thomas R. Cusack Pablo Beramendi
Investments in Electricity Generating Capacity under Different Market Structures and with Endogenously Fixed Demand

Zur Berücksichtigung von Kindern bei umlagefinanzierter Alterssicherung

Restraining the Genuine Homo Economicus: Why the Economy cannot be divorced from its Governance

Insisting on a Non-Negative Price: Oligopoly, Uncertainty, Welfare, and Multiple Equilibria

Buyer Power and Supplier Incentives

Monopoly Pricing with Negative Network Effects: the Case of Vaccines

The Breakdown of Authority

Equilibria in a Dynamic Global Game: The Role of Cohort Effects

Political Institutions and Income Inequality: The Case of Decentralization

Learning and Self-Confidence in Contests

The Introduction of New Product Qualities by Incumbent Firms: Market Proliferation versus Cannibalization

Impact of Uncertainty and Sunk Costs on Firm Survival and Industry Dynamics

Endemic Volatility of Firms and Establishments: Are Real Options Effects Important?

Private Monitoring in Auctions

Delay in Joint Projects

Product Market Competition and Lobbying

Coordination in the U.S. Mobile

Telecommunications Industry

Taxing Work: Some Political and Economic Aspects of Labor Income Taxation
SP II $2003-05$

SP || $2003-07$

SP || $2003-14$

SP || $2003-15$

SP II $2003-01$

SP II 2003-02

SP || $2003-03$

SP || $2003-06$

SP II 2003-08

SP || 2003-09

SP II $2003-10$

SP || 2003- 11

SP || 2003- 12

SP II $2003-13$

SP || $2003-16$

SP || $2003-17$ 

Bei Ihren Bestellungen von WZB-Papers schicken

Sie bitte unbedingt einen an Sie adressierten Auf-

kleber mit sowie je paper eine Briefmarke im Wert

von 0,51 Euro oder einen "Coupon Reponse Inter-

national " (für Besteller aus dem Ausland)
Please send a self addressed label and postage stamps in the amount of 0.51 Euro or a "CouponReponse International" (if you are ordering from outside Germany) for each WZB-paper requested

Absender / Return Address:

Wissenschaftszentrum Berlin

für Sozialforschung

Presse- und informationsreferat

Reichpietschufer 50

D-10785 Berlin-Tiergarten

Hiermit bestelle ich folgende(s)

Discussion paper(s):

Please send me the following Discussion paper(s):

Bestell-Nr. / Order no.

Autor/in, Kurztitel /Author(s) / Title(s) in brief 